\title{
DIOS MIO-The KISS Principle of the Ethical Approach to Copyright and Right of Publicity Law
}

\author{
Michael D. Murray*
}

\begin{abstract}
To copy or not to copy, to exploit the famous celebrity image or not to exploit it; these are the questions. The message of the modern legal world communicated through multiple voices in the academy is that copying often is perfectly acceptable and even laudable. An artist or designer might conclude that it is both legal and ethical to use whatever you can, use whatever you can get away with, and use it until you get sued for using it. Yet plagiarism in the arts and sciences is nearly universally condemned.

This Article proposes an ethical approach to the use of copyrighted works and names, images, and likenesses protected by the right of publicity. This approach is based on the ethical requirements of the law as synthesized from the cases presenting concrete narratives concerning fair and appropriate uses of protected works, names, and images. My thesis may be summed up in a revised form of the KISS principle (Keep it simple,

(C) 2013 Michael D. Murray

* Professor Michael D. Murray of Valparaiso University School of Law previously taught at the University of Illinois College of Law and at Saint Louis University School of Law. He has published eighteen books and treatises and numerous law review articles and essays on, among other subjects, art law, copyright, intellectual property law, legal profession and professional responsibility, legal research, and legal writing. This work was motivated by an invitation from the National Center for Professional \& Research Ethics to prepare an Ethics CORE encyclopedia article on ethics and intellectual property for artists and designers, Michael D. Murray, The Ethics of Intellectual Property: An Ethical Approach to Copyright and Right of Publicity Law (publication anticipated Spring 2013), and the current Article continues and builds on this project. Professor Murray thanks Gene Amberg (Illinois), Nick Burbules (Illinois), Brian Glassman (Cleveland Marshall), Tina Gunsalus (Illinois), Joan Sieber (National Center for Professional \& Research Ethics), and Melissa Weresh (Drake) for their support and peer-review during this project, and he thanks Rachel Williams for her research support.
\end{abstract}


stupid!) known as DIOS MIO:

\section{DIOS MIO}

Don't Include $\underline{\text { Other's }} \underline{\text { Stuff }}$

or

\section{Modify $\underline{\text { It }}$ Obviously}

Although simplified to this acronym, the ethical considerations concerning copyright-protected works and right of publicity-protected names and images are far from simple. The advice of this Article reflects the convergence of predominant purpose analysis and transformativel transformation analysis in copyright and right of publicity law that has led to a single set of recommendations for the legal and ethical treatment of protected works and celebrity names, images, and likenesses: seek first to create and not to copy or exploit, and create new expression by obvious modification of the old expression and content.

I. INTRODUCTION TO DIOS MIO 91

II.DON'T INCLUDE OTHER'S STUFF-THE ETHICS OF

CREATION

A. Bridging the Disconnect Between Plagiarism and Copying for Self-Expression or Self-

Actualization

B. Copying as Plagiarism Under Copyright and

Right of Publicity Law

1. The Copyright Originality Requirement and Its Parallels to Publicity Law

2. The Relationship Between Originality and Creativity .... 106

3. Plagiarism Is Not the Same As Following Techniques, Ideas, Methods, or Processes of Creation Under the Idea-Expression Distinction

4. The Parallels of Plagiarism and the Exploitation of a Celebrity's Name, Image, or Likeness

III. MODIFY IT OBVIOUSLY-THE ETHICS OF

TRANSFORMATION OF COPYRIGHTED WORKS

OR CELEBRITY IMAGES OR LIKENESS 
A. Transformation with a Predominant First Amendment Expressive Purpose in Copyright Fair Use Law.

B. Transformation with a Predominant First

Amendment Expressive Purpose in Right of

Publicity Fair Use Law.

IV. CONCLUSION

\section{INTRODUCTION TO DIOS MIO}

Should ethical designers or artists seek to steal and exploit as much copyrighted material and valuable celebrity names, images, and likenesses as they can get away with? Should an ethical approach to copyright and right of publicity law start with an examination of how best to exploit the legal defenses or gaps in coverage in the law or with a calculated analysis of how unlikely it would be to be sued? Do the voices of the legal academy who speak about the benefits of copying also encourage plagiarism in artistic creation? ${ }^{1}$ My answer to all of these questions is "no."

Copyright is the intellectual property protection of original and creative works including designs, images, writings, and artistic creations. Right of publicity is a right to control the use of a person's name, image, or likeness under legal theories that draw from intellectual property law, equity, privacy law, and property law. I have synthesized the law of copyright, right of publicity, and plagiarism, and both the legal rules and the narratives of case law applying the legal rules to actual, concrete situations that have arisen under the law to define a legal and ethical approach to the copying of others' works and aspects of their persona. This explanatory synthesis defines a

1. See Reuven Ashtar, Theft, Transformation, and the Need of the Immaterial: A Proposal for a Fair Use Digital Sampling Regime, 19 ALB. L.J. SCI. \& TECH. 261, 318 (2009); Wendy J. Gordon, An Inquiry into the Merits of Copyright: The Challenges of Consistency, Consent, and Encouragement Theory, 41 STAN. L. REV. 1343, 1444-45 (1989) [hereinafter Merits of Copyright]; Ashley M. Pavel, Reforming the Reproduction Right: The Case for Personal Use Copies, 24 BERKELEY TECH. L.J. 1615, 1642 (2009); John Tehranian, Whither Copyright? Transformative Use, Free Speech, and an Intermediate Liability Proposal, 2005 BYU L. REV. 1201, 1254-55; Rebecca Tushnet, Essay, Copy This Essay: How Fair Use Doctrine Harms Free Speech and How Copying Serves It, 114 YALE L.J. 535, 545-46 (2004) [hereinafter Copy This]. 
[Vol. 14:1

legal course that avoids stealing and exploiting the works or the good names and valuable images of other artists and celebrities. The proper, ethical concern of designers and artists should be whether it is appropriate in a legal and ethical sense to replicate works or images and likenesses at all, and if so, how the use should treat the underlying borrowed works, images, or likenesses.

An ethical approach to the use of copyrighted works and names, images, and likenesses protected by the right of publicity may be summed up in a revised form of the KISS principle (Keep it simple, stupid!) known as DIOS MIO:

\section{DIOS MIO}

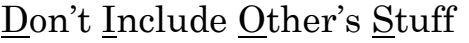

or

Modify It $\underline{\text { Obviously }}$

Although simplified to this acronym, the ethical considerations concerning copyright-protected works and right of publicity-protected names and images are far from simple. Fortunately, the same requirements of copyright law that call for the creation of original, copyrightable works also provide the incentive not to plagiarize because plagiarism most often produces unoriginal and, therefore, uncopyrightable works. In a similar way, an alteration of a copyrighted work or a valuable celebrity name, image, or likeness that creates new, original expression that predominates over the expression in the original not only fulfills originality requirements and avoids plagiarism but also would constitute a fair use of the original copyrighted work or celebrity name, image, or likeness. DIOS MIO reflects the current convergence of predominant purpose analysis and transformative/transformation analysis in copyright and right of publicity law that has led to a single set of recommendations for the legal and ethical treatment of protected works, names, and images.

\section{DON'T INCLUDE OTHER'S STUFF-THE ETHICS OF CREATION}

\section{A. BRIDGing the Disconnect BetweEn Plagiarism AND COPYING FOR SELF-EXPRESSION OR SELF-ACTUALIZATION}

The concept of plagiarism ties the act of copying with the 
motivation of exploitation, ${ }^{2}$ and thus it focuses attention on the ethics of using other people's valuable works or their names, images, or likenesses. The legal world hates plagiarism, ${ }^{3}$ but often seems to admire or even encourage certain types of copying. ${ }^{4}$ Plagiarism is held to be unethical, 5 even morally reprehensible, ${ }^{6}$ an offense carrying the badge of moral turpitude $^{7}$ that can suspend an attorney's license ${ }^{8}$ or deliver a

2. Plagiarism is an act of theft, a misappropriation of the ideas of others combined with explicit or implied misattribution to oneself to gain some advantage. See, e.g., BLACK'S LAW DICTIONARY 1267 (9th ed. 2009); see also K.R. ST. ONGE, THE MELANCHOLY ANATOMY OF PlaGIARISM 51-62 (1988).

3. See Carol M. Bast \& Linda B. Samuels, Plagiarism and Legal Scholarship in the Age of Information Sharing: The Need for Intellectual Honesty, 57 CATH. U. L. REV. 777, 780-81 (2008) (describing the views of the Legal Writing Institute and Judge Richard A. Posner); Lisa G. Lerman, Misattribution in Legal Scholarship: Plagiarism, Ghostwriting, and Authorship, 42 S. TEX. L. REV. 467, 467-68 (2001) (listing penalties for plagiarism in law school); Ralph D. Mawdsley, The Tangled Web of Plagiarism Litigation: Sorting Out the Legal Issues, 2009 BYU EDUC. \& L.J. 245, 246-47 (noting problems for faculty plagiarism); Laurie Stearns, Copy Wrong: Plagiarism, Process, Property, and the Law, 80 CAL. L. REV. 513, 529 (1992) ("A plagiarist, by falsely claiming authorship of someone else's material, directly assaults the author's interest in receiving credit."); see also Stuart P. Green, Plagiarism, Norms, and the Limits of Theft Law: Some Observations on the Use of Criminal Sanctions in Enforcing Intellectual Property Rights, 54 HASTINGS L.J. 167, 218-19 (2002) (analyzing the legal comparison between plagiarism and theft)

4. See, e.g., Merits of Copyright, supra note 1, at 1382-83; Pamela Samuelson \& Members of the CPP, The Copyright Principles Project: Directions for Reform, 25 BERKELEY TECH. L.J. 1175, 1192-93, 1228-29 (2010); Sara K. Stadler, Forging a Truly Utilitarian Copyright, 91 IowA L. REV. 609, 645-49 (2006); Copy This, supra note 1, at 568-74.

5. JOSEPH GIBALDI, MLA STYLe MANUAL AND GUIDE TO SchOlaRly PUBLISHING 151 (2d ed. 1998) ("Plagiarism is a moral and ethical offense rather than a legal one."); Bast \& Samuels, supra note 3, at 790; Kim D. Chanbonpin, Legal Writing, The Remix: Plagiarism and Hip Hop Ethics, 63 MERCER L. REV. 597, 601 (2012); see also Gerald Lebovits et al., Ethical Judicial Opinion Writing, 21 GEO. J. LEGAL ETHICS 237, 264 (2008) (explaining that extensively citing legal sources is acceptable, but that there is a fine line between citation and plagiarism).

6. Velez v. Alvarado, 145 F. Supp. 2d 146, 160-61 (D.P.R. 2001) (reprimanding lawyer for verbatim copying of a judge's opinion and order); Audrey Wolfson Latourette, Plagiarism: Legal and Ethical Implications for the University, 37 J.C. \& U.L. 1, 19, 29-50 (2010); Cooper J. Strickland, Recent Development, The Dark Side of Unattributed Copying and the Ethical Implications of Plagiarism in the Legal Profession, 90 N.C. L. REV. 920, 932$33(2012)$

7. Darby Dickerson, Facilitated Plagiarism: The Saga of Term-Paper Mills and the Failure of Legislation and Litigation to Control Them, 52 VILL. L. REV. 21, 58 (2007); Latourette, supra note 6, at 19. 
death sentence to a student's or academic's working life. ${ }^{9}$ Nevertheless, copying is sometimes described as a form of expression that facilitates communication in fulfillment of First Amendment values, 10 and to that extent, copying might be defended as a vehicle of self-expression and self-actualization, ${ }^{11}$ and an activity that furthers artistic growth and advances the arts. 12

8. See In re Lamberis, 443 N.E.2d 549, 550-53 (Ill. 1982) (upholding the suspension of an attorney's license for plagiarizing parts of an L.L.M. thesis); Iowa Sup. Ct. Atty. Disciplinary Bd. v. Cannon, 789 N.W.2d 756, 759 (Iowa 2010) (noting that the plagiarism amounted to a material misrepresentation); Iowa Sup. Ct. Bd. of Prof'l Ethics \& Conduct v. Lane, 642 N.W.2d 296, 297-98 (Iowa 2002) (censuring a lawyer for claiming fees for work that was largely plagiarized). Cf. In re Zbiegien, 433 N.W.2d 871, 871-72 (Minn. 1988) (finding that a student who plagiarized a paper during law school should be admitted to the bar).

9. ST. ONGE, supra note 2, at 39; Deborah R. Gerhardt, Plagiarism in Cyberspace: Learning the Rules of Recycling Content with a View Towards Nurturing Academic Trust in an Electronic World, 12 RICH. J.L. \& TECH. 1, 14 (2006); Latourette, supra note 6, at 7 ("[S]ome academics regard plagiarism as a capital offense potentially meriting the academic death knell for students and for faculty."); Kevin J. Worthen, Discipline: An Academic Dean's Perspective on Dealing with Plagiarism, 2004 BYU EDUC. \& L.J. 441, 442-44 (2004); see also RALPH D. MAWDSLEY, ACADEMIC MISCONDUCT: CHEATING AND PLAGIARISM 2-3 (1994) (noting that the punishments necessarily differ based on the position of the plagiarist).

10. See supra note 1 .

11. Wendy J. Gordon, A Property Right in Self-Expression: Equality and Individualism in the Natural Law of Intellectual Property, 102 YALE L.J. 1533, 1535-37 (1993); see also THOMAS I. EMERSON, THE SYSTEM OF FREEDOM OF EXPRESSION 6-7 (1970) (discussing the importance of freedom of expression);

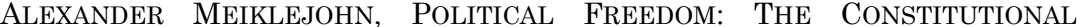
POWERS OF THE PEOPLE 54-60 (1960); C. Edwin Baker, Scope of the First Amendment Freedom of Speech, 25 UCLA L. REV. 964, 990-91 (1978); Alan Howard, The Constitutionality of Deceptive Speech Regulations: Replacing the Commercial Speech Doctrine with a Tort-Based Relational Framework, 41 CASE W. RES. L. REV. 1093, 1110-11 (1991); Joseph P. Liu, Copyright Law's Theory of the Consumer, 44 B.C. L. REV. 397, 415-17 (2003); Martin H. Redish, The Value of Free Speech, 130 U. PA. L. REV. 591, 593-94 (1982). Several justices have spoken eloquently on the importance of free speech. See, e.g., Whitney v. California, 274 U.S. 357, 375-76 (1927) (Brandeis, J., concurring); Abrams v. United States, 250 U.S. 616, 630 (1919) (Holmes, J., dissenting).

12. Olufunmilayo B. Arewa, The Freedom to Copy: Copyright, Creation, and Context, 41 U.C. DAVIS L. REV. 477, 488 (2007) ("[P]roblems arise from the reality of borrowing and other techniques that involve some degree of copying as important elements in the creation of new works."); David A. Simon, Culture, Creativity, \& Copyright, 29 CARDOZO ARTS \& ENT. L.J. 279, 322-25 (2011); see also LAWRENCE LESSIG, REMIX: MAKING ART \& COMMERCE THRIVE IN A HYBRID ECONOMY 17-19 (2009); KEMBREW McLeOD ET AL., CREATIVE LICENSE: The LAW AND CULTURE OF DigITAL SAMPLING 11-16 (2011); Julie E. 
In order to bridge the obvious disconnect between the abhorrence of plagiarism and the toleration or tacit encouragement of certain forms of copying, the study of law and ethics must recognize that plagiarism has been associated with the theft of ideas and the words and images that embody and express those ideas for the purpose of gaining an advantagepersonal or professional credit, recognition, an academic grade, or remuneration-as a result of that theft. ${ }^{13}$ Thus, plagiarism is a form of exploitation, but one that is primarily concerned with the theft and misattribution of ideas and insights to the credit of the plagiarist. ${ }^{14}$ Plagiarism is a form of kidnapping and enforced servitude of abducted ideas ${ }^{15}$ - the activity of an intellectual press-gang that shanghais a crew of ideas and

Cohen, Creativity and Culture in Copyright Theory, 40 U.C. DAVIS L. REV. 1151, 1179-80 (2007) [hereinafter Creativity and Culture] (noting methods that creativity can stem from a shared cultural heritage); Julie E. Cohen, The Place of the User in Copyright Law, 74 FoRDHAM L. REV. 347, 348-49 (2005); Peter Jaszi, On the Author Effect: Contemporary Copyright and Collective Creativity, 10 CARDOZO ARTS \& ENT. L.J. 293, 304 (1992); Liane Gabora, The Origin of Evolution of Culture and Creativity, 1 J. MEMETICS $§ 5$ (1997), available at http://www.imagomundi.com.br/cultura/memes_gabora.pdf ("The ideas and inventions any one individual produces build on the ideas and inventions of others.").

13. See Green, supra note 3, at 173 (noting that plagiarism does not credit the original source); David A. Thomas, How Educators Can More Effectively Understand and Combat the Plagiarism Epidemic, 2004 BYU EDUC. \& L.J. 421, 422-23 (noting that plagiarism definitions must work around traditions of acceptable and unacceptable copying). But see RICHARD A. Posner, THE LITTLE BOOK OF PLAGIARISM 11 (2007) (considering plagiarism as not necessarily literary theft). The Legal Writing Institute's definition of plagiarism specifically refers to "literary property," describing plagiarism as "[the t]aking [of] the literary property of another, passing it off as one's own without appropriate attribution, and reaping from its use any benefit from an academic institution." LEGAL WRITING INST., LAW SCHOOL PLAGIARISM V. PROPER ATTRIBUTION 2 (2003) [hereinafter LAW SCHOOL PlaGIARISM], available at http://www.lwionline.org /publications/plagiarism/policy.pdf.

14. See Green, supra note 3, at 174-75; see also Thomas, supra note 13 , at 426-28 (describing reasons why a student might decide to plagiarize another's work); POSNER, supra note 13, at 11-12 (noting that theft is a misleading term but that classifying it as "borrowing" is also misleading).

15. The term "plagiarism" comes from the Latin word "plagiarius," meaning a kidnapper. LANGENSCHEIDT'S POCKET LATIN DICTIONARY 242 (1966); see also Katharina de la Durantaye, The Origins of the Protection of Literary Authorship in Ancient Rome, 25 B.U. INT'L L.J. 37, 71 (2007); Jaime S. Dursht, Note, Judicial Plagiarism: It May Be Fair Use But is it Ethical?, 18 CARDOZO L. REV. 1253, 1263 (1996) (citing WEBSTER's NEW DICTIONARY OF THE LANGUAGE 803 (1966)); Stearns, supra note 3, at 517 (citing 11 THE OXFORD ENGLISH DICTIONARY 947 (2d ed. 1989)). 
forces them to work for the abductor. ${ }^{16}$ Plagiarism in the arts and literature involves: (1) an intentional taking, (2) of creative literary or artistic works of another, (3) without attribution, (4) passing them off as one's own, (5) without adding significant artistic or literary value to the copied material, and (6) with the potential to reap an unearned benefit or earn an undeserved credit from the use. ${ }^{17}$

The form of "naked copying" favored by commentators is copying that furthers First Amendment goals of communicating expression about culture, or one's personal human condition, or other educational, historical, and archival uses of prior works. ${ }^{18}$ Certain forms of copying-for archiving, transmission of knowledge, education, and self-expression-have enormous societal benefits that rival the public policies supporting the protection of intellectual property. ${ }^{19}$ There is a balance that must be struck when determining the limits of a copyright monopoly that curtails many forms of copying including the kinds of copying that benefit society. But nothing in this equation supports plagiarism. Plagiarism is neither a prescription nor a substitute for the creative goals of artists and designers who attempt to create works for the benefit of being known for and credited with the content of the works. ${ }^{20}$

16. See Durantaye, supra note 15 , at 71 ("The term initially referred to the kidnapping of free men and the selling of them into slavery."); Dursht, supra note 15, at 1263 ("In Roman law, plagium was the act of stealing a slave from his master and was a criminal offense."); Stearns, supra note 3, at 517 ("The image [of plagiarism] is more nearly that of abduction into servitude...."); see also ALEXANDER LINDEY, PLAGIARISM AND ORIGINALITY 95 (1952)

17. See LAW SCHOOL PlagiarisM, supra note 13, at 2; Stearns, supra note 3 , at 516-17; see also supra note 2 and accompanying text.

18. See, e.g., Creativity and Culture, supra note 12, at 1174-76; Guy Pessach, [Networked] Memory Institutions: Social Remembering, Privatization and its Discontents, 26 CARDOZO ARTS \& ENT. L.J. 71, 82-83, 135-38 (2008); Pamela Samuelson, Unbundling Fair Uses, 77 FordHAM L. REV. 2537, 256576 (2009); John Tehranian, Parchment, Pixels, \& Personhood: User Rights and the IP (Identity Politics) of IP (Intellectual Property), 82 U. COLO. L. REV. 1, 45, 48-49 (2011); Copy This, supra note 1, at 545-48.

19. Cf. supra note 18 and accompanying text.

20. See Green, supra note 3, at 200-05; Stearns, supra note 3, at 543-44; Rebecca Tushnet, Payment in Credit: Copyright Law and Subcultural Creativity, 70 LAW \& CONTEMP. PROBS. 135, 151, 155-56 (2007) [hereinafter Payment in Credit] ("[F] an creators are usually highly concerned with proper attribution. Plagiarism . . . is one of the most serious offenses against the fan community, and when the plagiarism is discovered, fans are likely to publicly 
Furthermore, "[w]hen a public figure is charged with plagiarism, the public concern is not primarily about protecting the possessory interests of the 'owner' of the stolen [works]. Instead, society sees itself as the victim of duplicity and is interested in passing judgment on the character of the plagiarist." 21 Plagiarism does not benefit society; it is a cheat and a fraud upon society. ${ }^{22}$

Part of the confusion concerning the contours of copyright protection compared to the scope of the concept of plagiarism arises from the different policies supporting the two concepts. ${ }^{23}$ Plagiarism is not about the issue of who should be able to exploit a valuable property right so much as it is concerned with the fairness of taking credit for ideas and insights one did not think up or imagine, and thereby cheating not only the true original thinker, but the entire community that bestows credit and accolades on original thinkers. ${ }^{24}$ Authors have described plagiarism as a defect in process and copyright infringement as a defect in result. ${ }^{25}$ Plagiarism has a mental component of cheating and intentional misrepresentation or misattribution, while copyright infringement has no mental component and only focuses on the end product and whether it is a copy or an unauthorized derivative work of the original regardless of the mental state of the copyist. ${ }^{26}$ In plagiarism, the end product has

excoriate the plagiarist.").

21. Greg Lastowka, The Trademark Function of Authorship, 85 B.U. L. REV. 1171, 1185 (2005)

22. See id. at 1184-85. "[C]ontrary to the impression one might gain from reading the many judicial opinions that conflate copyright infringement with plagiarism, there is no law prohibiting plagiarism and misattribution generally." Id. at 1210-11.

23. See Jonathan Band \& Matt Schruers, Dastar, Attribution, and Plagiarism, 33 AIPLA Q.J. 1, 3-6 (2005); Green, supra note 3, at 200-01; Ralph D. Mawdsley, Plagiarism Problems in Higher Education, 13 J.C. \& U.L. 65, 87-90 (1986) [hereinafter Plagiarism Problems].

24. See Dursht, supra note 15, at 1263-66; Gerhardt, supra note 9, at 1416; Green, supra note 3, at 234-35 (noting the effect on scholars who are plagiarized); Latourette, supra note 6, at 21; Stearns, supra note 3, at 529; see also Payment in Credit, supra note 20, at 155-56 (explaining the importance of lack of attribution or "credit" in plagiarism analysis compared to the unimportance of attribution in copyright-intellectual property analysis).

25. Dursht, supra note 15 , at 1270 n.113; Stearns, supra note 3, at 52425 .

26. See LINDEY, supra note 16, at 232; Jon M. Garon, Normative Copyright: A Conceptual Framework for Copyright Philosophy and Ethics, 88 CORNELL L. REV. 1278, 1290-91 (2003) (explaining that copyright is tied to the 
little to do with the charge-even clever paraphrasing and creative compilations of other people's thoughts would constitute plagiarism if the copyist has the mental state to steal and take credit for the stolen thoughts. ${ }^{27}$ Plagiarism is not a crime, ${ }^{28}$ but a violation of ethics, morality, and equity, ${ }^{29}$ and an act of fraud or negligent misrepresentation. ${ }^{30}$ Plagiarism, like other forms of piracy, receives little aid and comfort from legal theorists. ${ }^{31}$

Artists and designers also might be confused by the fact that the scopes of enforcement of plagiarism and copyright infringement do not completely overlap. ${ }^{32}$ Plagiarism primarily is an ethical offense, not a crime or civil wrong, while unauthorized copying of creative works has been regulated by laws of intellectual property and, in particular, the copyright laws. ${ }^{33}$ Strangely enough, unlike plagiarism, willful copying for

reaping of unearned benefits); Latourette, supra note 6, at 22 (explaining that the intent of plagiarism is essential); Stearns, supra note 3, at 516-17. But see Green, supra note 3, at 181-86 (noting that requiring intent could give some plagiarists room to avoid punishment).

27. Dursht, supra note 15, at 1281 ("[P]lagiarism focuses on the process of copying."); Latourette, supra note 6, at 22; Stearns, supra note 3, at 516-17.

28. Dursht, supra note 15, at 1258 (explaining that plagiarism is an ethical offense often prohibited by academic ethics codes); Latourette, supra note 6 , at 18-19 Green, supra note 3, at 228-35, (discussing the propriety of a change in the law to criminalize plagiarism).

29. See Bast \& Samuels, supra note 3, at 790; Dursht, supra note 15, at 1256; Latourette, supra note 6, at 19; see also Yu v. Univ. of La Verne, 126 Cal. Rptr. 3d 763, 767-68 (Ct. App. 2d Dist. 2011); Hanifi v. Board of Regents, 46 Ill. Ct. Cl. 131, 135 (1994) (noting plagiarist's admissions that such conduct is unethical); In re Lamberis, 443 N.E.2d 549, 551-52 (Ill. 1982); Iowa Sup. Ct. Bd. of Prof'l Ethics \& Conduct v. Lane, 642 N.W.2d 296, 300 (Iowa 2002); In re Zbiegien, 433 N.W.2d 871, 879 (Minn. 1988) (Kelley, J., dissenting) (disagreeing with the majority ruling allowing plagiarist to be admitted to the bar).

30. ST. ONGE, supra note 2, at 101; see also Lane, 642 N.W.2d at 300.

31. See, e.g., Marcel C. Lafollette, Stealing into Print: Fraud, Plagiarism, AND Misconduct IN SCIENTIFIC PUBlishing 1 (1992); LindeY, supra note 16, at chs. 10, 14, 15; Robert D. Bills, Plagiarism in Law School: Close Resemblance of the Worst Kind?, 31 SANTA CLARA L. REV. 103, 103 (1990); Dursht, supra note 15, at 1281.

32. Band \& Schruers, supra note, 23, at 3-6; Bast \& Samuels, supra note 3 at 790; Green, supra note 3, at 200-02; Samuel J. Horovitz, Note, Two Wrongs Don't Negate a Copyright: Don't Make Students Turn it in if You Won't Give It Back, 60 FLA. L. REV. 229, 255-58 (2008); Plagiarism Problems, supra note 23 , at $87-88$.

33. Bast \& Samuels, supra note 3, at 790-91; Merits of Copyright, supra note 1, at 1465; Michael D. Murray, Copyright, Originality, and the End of the 
personal gain and commercial distribution has been defined as a criminal offense. ${ }^{34}$

The public policy behind the copyright laws is " $t$ to promote the Progress of Science and useful Arts, by securing for limited Times to Authors and Inventors the exclusive Right to their respective Writings and Discoveries." 35 Additionally, "[i]ts constitutional goal is to promote enlightenment, not retard it'to increase and not to impede the harvest of knowledge.' The property rights it establishes must 'ultimately serve the cause of promoting broad public availability of literature, music, and the other arts." 36

Copyright has carved out specific areas in which copying is held to be perfectly legal-the creation and recognition of a public domain (or public domains), ${ }^{37}$ the doctrine of originality with the supporting doctrines of merger and scènes à faire, ${ }^{38}$

Scènes à Faire and Merger Doctrines for Visual Works, 58 BAYLOR L. REV. 779, 785-86 (2006) [hereinafter Copyright Originality] ("The artist or author's creative expression and embodiment of the idea is protected.").

34. 17 U.S.C. § 506 (2006); see also Steven K. Barton, Note, Felony Copyright Infringement in Schools, 1994 BYU EDUC. \& L.J. 143, 144-48 (describing the elements necessary for the criminal offense); Geraldine Szott Moohr, The Crime of Copyright Infringement: An Inquiry Based on Morality, Harm, and Criminal Theory, 83 B.U. L. REV. 731, 736-37 (2003).

35. U.S. ConsT. art. I, $\S 8, \mathrm{cl} .8$.

36. James Gibson, Once and Future Copyright, 81 Notre DAME L. REV. 167, 218 (2005) (citations omitted).

37. See, e.g., Julie E. Cohen, Copyright, Commodification and Culture: Locating the Public Domain, in THE FUTURE OF THE PUBLIC DOMAIN 121, 124 135 (Lucie Guibault \& P. Bernt Hugenholtz eds., 2006); James Boyle, The Second Enclosure Movement and the Construction of the Public Domain, 66 LAW \& CONTEMP. PROBS. 33, 59-64 (2003); M. William Krasilovsky, Observations on the Public Domain, 14 BULL. COPYRIGHT SOC'Y U.S.A. 205, 205-06 (1967); Jessica Litman, The Public Domain, 39 EMORY L.J. 965, 96768 (1990); Tyler T. Ochoa, Origins and Meanings of the Public Domain, 28 U. DAYTON L. REV. 215, 217-22 (2002); Pamela Samuelson, Enriching Discourse on Public Domains, 55 DUKE L.J. 783, 784 (2006) (mentioning the possibility of multiple public domains); Pamela Samuelson, Mapping the Digital Public Domain: Threats and Opportunities, LAW \& CONTEMP. PROBS., Winter \& Spring 2003, at 147, 148-53; see also David Lange, Recognizing the Public Domain, 44 LAW \& CONTEMP. PROBS. 147 passim (1981) (arguing that the scope of the public domain must be clear from encroachment by intellectual property rights).

38. Melville B. Nimmer \& DAVID Nimmer, Nimmer on COPYRIGHT § 13.03[B][3]-[4] (Matthew Bender, rev. ed. 2012); Leslie A. Kurtz, Copyright: The Scenes a Faire Doctrine, 41 FLA. L. REV. 79, 91-92 (1989); Douglas Lichtman, Copyright as a Rule of Evidence, 52 DUKE L.J. 683, 734-39 (2003); Lateef Mtima, So Dark the Con(Tu) Of Man: The Quest for a Software 
and the definition of what is infringement versus what is fair use ${ }^{39}$ - to facilitate legally-recognized acts of copying.

Because the overlap between plagiarism and copyright infringement is incomplete, an act of plagiarism may or may not be an act of copyright infringement, and the converse also is true. ${ }^{40}$ This is particularly true in the visual arts because copyright law precludes ideas from being copyrighted (i.e., from being protected from copying), and infringement requires the copying to be of a work, which is an expression of the ideas. ${ }^{41}$ If an act of copying implicates the theft of ideas and misattribution of a prior author's ideas and insights to the credit of the copyist, it may well constitute an act of plagiarism. ${ }^{42}$ It will not constitute an act of copyright infringement unless the scenario includes the copying of a

Derivative Work Right in Section 117, 69 U. PITT. L. REV. 23, 94-99 (2007); Copyright Originality, supra note 33, at 788-98.

39. See 17 U.S.C. § 107 (2006) (defining fair use); Barton Beebe, An Empirical Study of U.S. Copyright Fair Use Opinions, 1978-2005, 156 U. PA. L. REV. 549, 551-57 (2008) (using statistical analysis to describe the contradictions in fair use case law); Dan L. Burk, Muddy Rules for Cyberspace, 21 CARDOZO L. REV. 121, 140 (1999) (describing how it is impossible to determine whether use is fair before litigation because of a balancing test); Jeanne C. Fromer, Claiming Intellectual Property, 76 U. CHI. L. REV. 719, 74549 (2009); Pierre N. Leval, Toward a Fair Use Standard, 103 HARV. L. REV. 1105, 1106-07 (1990) (noting many gaps in fair use jurisprudence); Michael D. Murray, What is Transformative? An Explanatory Synthesis of the Convergence of Transformation and Predominant Purpose in Copyright Fair Use Law, 11 CHIC.-KENT J. INTELL. PROP. 260 (2012) [hereinafter What is Transformative?] (discussing how an explanatory synthesis demonstrates the operation of the transformative test); Neil Weinstock Netanel, Making Sense of Fair Use, 15 LEWIS \& CLARK L. REV. 715, 719-20 (2011) (critiquing the four factor test used by courts); R. Anthony Reese, Transformativeness and the Derivative Work Right, 31 ColuM. J.L. \& ARTS 467, 467-69 (2008); Elizabeth L. Rosenblatt, A Theory of IP's Negative Space, 34 CoLUM. J.L. \& ARTS 317, 334-36 (2011); Matthew Sag, Predicting Fair Use, 73 OHIO ST. L.J. 47, 53-63 (2012) (empirical study of fair use); Samuelson, supra note 18, at 2539-41 (comprehensive study of fair use doctrine's unpredictability).

40. See Band \& Schruers, supra note 23, at 3-6; Bast \& Samuels, supra note 3 , at 790; Green, supra note 3 , at 200-02; Horovitz, supra note 32 , at 255-58; Plagiarism Problems, supra note 23, at 87-88.

41. See 17 U.S.C. § 102(b) (2006); see also Jon M. Garon, Playing in the Virtual Arena: Avatars, Publicity, and Identity Reconceptualized Through Virtual Worlds and Computer Games, 11 CHAP. L. REV. 465, 477-78 (2008); Copyright Originality, supra note 33, at 788-90; Robert H. Rotstein, Beyond Metaphor: Copyright Infringement and the Fiction of the Work, 68 CHI.-KENT L. REV. 725, 758 (1993).

42. See supra note 17 and accompanying text. 
particular form of expression of the ideas. Copying of public domain works or any copying permitted by the originality doctrines and fair use defenses will not be infringement, but it may well constitute plagiarism if the copyist potentially will receive personal recognition or benefit as the "creator" of the copied material. ${ }^{43}$ On the other hand, outside of the protections of the doctrines of originality and the public domain, and the fair use defenses mentioned here, the copying of one author's work and incorporating it into a new work might constitute infringement no matter if the copyist gives proper attribution and recognition to the author and source of the copied material to such a degree that there is no possibility of a finding of plagiarism in the scenario.

The distinction between plagiarism and copyright infringement is more powerful in theory than in practice. ${ }^{44}$ Plagiarism almost always involves the copying of expressionwe would be at a loss to know what ideas have been taken by the plagiarist if not for the ability to trace the plagiarist's expression to its unacknowledged source. In some disciplines of the arts and sciences, a plagiarist might steal an actual idea-a scholarly insight, a scientific discovery, or a historical conjecture-and attempt to obtain the recognition for the essential ideas represented by these concepts without much concern for whether or not the plagiarist actually copied the original words or forms in which the ideas once were expressed by the original author of the ideas. ${ }^{45}$ But in the visual arts, the concern is with the act of taking another artist's worksexpressions, not ideas-without attribution and with the intent of gaining the credit and recognition for an act of creation. ${ }^{46}$ Taking works, rather than the idea of works, still is an ethical wrong known as plagiarism even if copyright law does not afford the original artist or her heirs a cause of action because the work fell into the public domain or because the strength of the copyright over the original work was lessened by one of the

43. See supra notes 37-39.

44. See Green, supra note 3, at 181-86 (explaining how unintentional plagiarism still falls within the scope of plagiarism, even though plagiarism is often distinguished from copyright by its mental element).

45. See Payment in Credit, supra note 20, at 155-56 (explaining how proper attribution is considered to be important by the community for fan created works).

46. See supra note 20 and accompanying text. 
originality doctrines of merger or scènes à faire. ${ }^{47}$ The distinction revolves around the wrong defined by plagiarismmisappropriation with the intent to receive a benefit from the theft-as opposed to copyright's concern with allocation of the rights to use and exploit a valuable property right in expression. The Parts that follow trace the legal requirements of copyright law, copyright infringement, and fair use to define the legal and ethical path for artists and designers with respect to the works of other artists and designers.

With regard to the right of publicity, very few uses of a celebrity name, image, or likeness have the tendency to impute the reputation and good will of the celebrity to the infringer in the sense that one would admire the person of the infringer for the same traits and attributes as the celebrity. ${ }^{48}$ Right of publicity violations are an exploitation of a celebrity's name, image, and reputation, but the benefit sought generally is not personal or professional credit, an academic grade, or accolades. ${ }^{49}$ The infringer does not seek to be known as the celebrity; he or she merely seeks attention, marketing advantages, or other benefits from the misassociation of the star power of the celebrity with the infringer's own works or activities. As a result, most violations of the right of publicity will not also constitute plagiarism. Therefore, simply reminding artists and designers of the concept of plagiarism is an incomplete prescription for proper treatment of others' names, images, and likenesses.

In the Parts that follow, I have synthesized the ethical and moral underpinnings of plagiarism with the public policy underlying copyright and right of publicity law to make a more complete statement of legal and ethical behavior with respect

47. See supra note 38 . In essence, the originality doctrines allow copying when the material copied was not and could not have been copyrighted. If the original work is limited by the merger doctrine (there are only a limited number of ways to express the concept, and both authors used one of these limited ways), or scènes à faire (both authors used a stock scene, a natural, realistic depiction of the same object, or some other necessary phrasing or depiction "that must be done" to express the idea of the scene), then there will be no grounds for a claim of copyright infringement even if the scenario reeks of plagiarism. See Copyright Originality, supra note 33, at 788-89, 794.

48. See Leval, supra note 39, at 1132 (noting the ease of copying and undercutting tangible goods, such as fabric patterns, fashion accessories, and toys).

49. See supra note 13 and accompanying text. 
to the works and the names and images of other artists, designers, and celebrities. In spite of the distinctions between the ethical conception of plagiarism and the legal definitions of copyright and right of publicity infringement, the end result is the same recommendation, "Don't Include Other's Stuff."

\section{B. Copying as PlaAgIarism Under Copyright AND Right of PUBLICITY LAW50}

Plagiarism is unethical.51 The act of copying with the intention and expectation of receiving credit for the copied material is plagiarism. ${ }^{52}$ Plagiarism is not excusable as selfexpression or self-actualization when the act of copying is to gain credit for someone else's creative act. ${ }^{53}$

Artists and designers seek to create. The application of the creative faculties of the mind to the creation of art works and designs is the exact activity toward which artists and designers devote their talents. It is easy to understand the measure of achievement and distinction in the arts and design world: it is to be known for being original, not derivative, to produce new works of distinction and individual genius, not to replicate the works of the past. The appellations, "derivative" or "copycat," in the arts and design world are as damning an appellation as being called a "plagiarist" in the literary and academic world. Replication is a short-cut, not an achievement of merit. Fortunately, copyright law recognizes the priority of the creation of new, non-duplicative, non-derivative works as being the quintessential achievement for copyright purposes too. Thus, striving for achievement and distinction in the arts and design world produces successful legal and ethical results under copyright law.

50. As mentioned previously, the research that produced this Article was motivated by an invitation from the National Center for Professional \& Research Ethics to prepare an Ethics CORE Encyclopedia article on ethics and intellectual property for artists and designers. Michael D. Murray, The Ethics of Intellectual Property: An Ethical Approach to Copyright and Right of Publicity Law (July 12, 2012) (unpublished manuscript), available at http://papers.ssrn.com/sol3/papers.cfm?abstract_id=2013463. Also see information provided in the author's biography at the beginning of this Article.

51. See supra notes 28-30.

52. See supra notes 3, 12-13, 24 and accompanying text.

53. See Stearns, supra note 3 , at 514 . 
1. The Copyright Originality Requirement and Its Parallels to Publicity Law

The creation of original expression is the essential requirement for a copyrightable work. ${ }^{54}$ "The sine qua non of copyright is originality." 55 Originality is the very "premise of copyright law." 56

The definition of original is "not copied," 57 rather than something that is entirely new, fresh, novel, and excessively creative. 58 "Originality does not signify novelty; a work may be original even though it closely resembles other works so long as the similarity is fortuitous, not the result of copying." 59 Nevertheless, this definition feeds directly into the recommended approach to the fair and ethical use of others' works: if you do not copy, you will be playing fairly with others' works and you will be creating works that will be copyrightable in the process.

Copyright law is concerned only with the copying of words and images that constitute expressions of ideas. ${ }^{60}$ In copyright law, the idea-expression distinction prevents copyright from quashing new, original expression derived from the ideas depicted or embodied in other works by forbidding the exercise of copyright protection over ideas, including themes,

54. Feist Publ'ns, Inc. v. Rural Tel. Serv. Co., 499 U.S. 340, 347 (1991); Stewart v. Abend, 495 U.S. 207, 247-48 (1990) (Stevens, J., dissenting); see also Goldstein v. California, 412 U.S. 546, 561-62 (1973).

55. Feist, 499 U.S. at 345.

56. Id. at 347 (quoting Miller v. Universal City Studios, Inc., 650 F.2d 1365, 1368 (5th Cir. 1981)).

57. Id. at 346-47; Burrow-Giles Lithographic Co. v. Sarony, 111 U.S. 53, 58 (1884); The Trade-Mark Cases, 100 U.S. 82, 94 (1879).

58. Feist, 499 U.S. at 345; Mazer v. Stein, 347 U.S. 201, 218 (1954) (“[C]opyright protects originality rather than novelty or invention ...."). In contrast, patent protection requires an invention that is novel and nonobvious. 35 U.S.C. $\S \S 102-103$ (2006).

59. Feist, 499 U.S. at 345.

60. See Copyright Originality, supra note 33, at 785-86; Raymond T. Nimmer \& Patricia Ann Krauthaus, Software Copyright: Sliding Scales and Abstracted Expression, 32 Hous. L. REV. 317, 323, 331-32 (1995); Pamela Samuelson, Copyright and Freedom of Expression in Historical Perspective, 10 J. INTELL. PROP. L. 319, 319-20 (2003); see also Rebecca Tushnet, Worth a Thousand Words: The Images of Copyright, 125 HARV. L. REV. 683, 684-85, 710-12 (2012) (explaining that copyright began with the protection of words alone and has struggled to fit images into its scheme). 
techniques, processes, and procedures. ${ }^{61}$ The idea-expression distinction preserves certain forms of copying of ideas from copyright infringement because they result in new, original expression that is not traced back to an earlier source-in other words, the artist or designer is not credited with the invention or conception of the technique, process, or procedure in the arts, or with the theme, genre, or device in the arts or literature, but simply with the new, original expression embodying the idea. ${ }^{6}$ Many artists may follow a formula or genre for artistic or literary success, and copyright law recognizes that by defining genre and formula as ideas that may be used by any and all artists and authors under the idea-expression distinction. ${ }^{63} \mathrm{We}$ are quite comfortable with hundreds of modern and contemporary mystery-crime-detective writers and confuse none of them with Wilkie Collins or Edgar Allan Poe. We are quite taken with scores of modern and contemporary impressionistic painters, and confuse none of them with Monet, Renoir, or Morisot. But a plagiarist seeking recognition for content-expression-copied from another artist receives our ire for this unethical trick. ${ }^{64}$

Right of publicity law defines and protects the right to control the use of one's name, image, likeness, or other valuable attributes of one's persona by others when others seek to use these things for personal gain or commercial advantage.65 There is no idea-expression distinction in right of publicity law; the celebrity's image and likeness are the subject matter of the right, and there is no "idea" of a celebrity that is free to all for

61. See 17 U.S.C. § 102(b) (2006); see also Garon, supra note 41, at 47778; Copyright Originality, supra note 33, at 788-89; Rotstein, supra note 41, at 758 (noting that courts and scholars have found the distinction difficult to apply); Haochen Sun, Overcoming the Achilles Heel of Copyright Law, 5 Nw. J. TECH. \& INTELL. PROP. 265, 307-08 (2007).

62. See Garon, supra note 41 , at $477-78$

63. See Copyright Originality, supra note 33, at 791.

64. See supra notes 5-9 and accompanying text. Forgery is another unethical and illegal behavior involving copying, but it is the inverse of plagiarism because the forger seeks no recognition (or blame) for the copy, and only seeks to have it falsely attributed to the original artist. See Stearns, supra note 3 , at 517 .

65. See, e.g., N.Y. CIV. RIGHTS LAW §§ 50, 51 (McKinney 2009); CAL. CiV. CODE $§ 3344$ (West 1997); RESTATEMENT (THIRD) OF UNFAIR COMPETITION $\S$ 46 (1995); J. Thomas MCCARThy, The Rights of PUBlicity AND PRIVACY $\S$ 3:2 (2d ed. 2006) [hereinafter PUBLICITY AND PRIVACY]. 
reproduction or new expression. 66 Therefore, even expression that calls the celebrity to mind without reproducing the actual image or likeness of the celebrity is actionable. ${ }^{67}$

An element of the right of publicity offense is the gaining of an advantage from the exploitation of a valuable celebrity persona, which matches the mental state of plagiarism which seeks credit or benefit from the exploitation of another's valuable ideas. 68 The two wrongs are parallel rather than overlapping, but result in the same ethical recommendation not to exploit another person for personal gain. This pushes the discussion toward answering the question of what is exploitation versus what is fair use, which will be discussed further below.

\section{The Relationship Between Originality and Creativity}

Originality is connected to creativity, but only in the following manner: a copyrightable work must be created-it must be a work of authorship "founded in the creative powers of the mind." 69 When combined, the two requirements mean that a copyrightable work is one that is not copied and is conceived of by the author.

66. See F. Jay Dougherty, All the World's Not a Stooge: The "Transformativeness" Test for Analyzing a First Amendment Defense to a Right of Publicity Claim Against Distribution of a Work of Art, 27 ColUM. J.L. \& ARTS 1, 32-33, 52, 70-71 (2003); Peter Johnson, Can You Quote Donald Duck?: Intellectual Property in Cyberculture, 13 YALE J.L. \& HUMAN. 451, 46263 (2001) (reviewing ROSEMARY J. COOMBE, THE CULTURAL LIFE OF INTELLECTUAL PROPERTIES: AUTHORSHIP, APPROPRIATION, AND THE LAW (1998)); Jennifer E. Rothman, Copyright Preemption and the Right of Publicity, 36 U.C. DAVIS L. REV. 199, 252-54 (2002); David S. Welkowitz \& Tyler T. Ochoa, Teaching Rights of Publicity: Blending Copyright and Trademark, Common Law and Statutes, and Domestic and Foreign Law, 52 ST. LOUIS U. L.J. 905, 910 (2008); see also White v. Samsung Elecs. Am., Inc., 989 F.2d 1512, 1516 (9th Cir. 1993) (Kozinski, J., dissenting).

67. See, e.g., White v. Samsung Elecs. Am., Inc., 971 F.2d 1395, 1399 (9th Cir. 1992) (finding that robot animation called to mind Vanna White's "Wheel of Fortune" persona); Carson v. Here's Johnny Portable Toilets, Inc., 698 F.2d 831, 835 (6th Cir. 1983) (finding that product name called to mind Johnny Carson's "Tonight Show" persona).

68. See supra note 19 and accompanying text.

69. Feist Publ'ns, Inc. v. Rural Tel. Serv. Co., 499 U.S. 340, 346 (1991) (quoting The Trade-Mark Cases, 100 U.S. 82, 94 (1879)); see also Eldred v. Ashcroft, 537 U.S. 186, 211 (2003) (addressing the issue of whether Congressional copyright extensions address Constitutional requirements for originality and creativity). 
The works which are to be protected by copyright must be "the fruits of intellectual labor, embodied in the form of books, prints, engravings, and the like." 70 The creativity required does not have to be at a genius level: "[T]he requisite level of creativity is extremely low; even a slight amount will suffice. The vast majority of works make the grade quite easily, as they possess some creative spark, "no matter how crude, humble or obvious' it might be."71

The definition of creativity in copyright law may be comforting to those who question their own innovativeness and uniqueness-the law sets a low bar for creative aptitude and imagination-but the definition does communicate a meaningful message when coupled with the legal requirement of originality and the ethical prohibition against plagiarism: it means your creative inspiration cannot revolve around copying the work of another artist.

Plagiarism does not automatically produce inferior worksin fact, although it is ironic to note it, plagiarism of great works, embodying great ideas, superior technique, and impressive creativity, often produces a result that is superior in many ways to works that plagiarists might have produced on their own. ${ }^{72}$ The problem is that plagiarized works are not "new" although they appear to be new, they are not a product of the hand or the mind of the plagiarist, although they appear to be, and they are attributed and credited to the plagiarist at the expense of the original creator in a manner that cheats the audience of the "new" works. ${ }^{73}$ In a legal sense, the copyright originality and creativity elements require works to be new, not copied, and require a creation that is conceived of by the mind and executed by the hand or at the direction of the artist. ${ }^{74}$ Fulfilling these same elements also will avoid a charge of plagiarism regarding creative works that are to be attributed to

70. Feist, 499 U.S. at 346 (quoting The Trade-Mark Cases, 100 U.S. 82, 94 (1879)); see also Eldred, 537 U.S. at 211 (noting that there is a narrow category of works where copyright cannot exist); Mazer v. Stein, 347 U.S. 201, 213-15 (1954) (explaining that the scope of such rights is granted by Congress).

71. Feist, 499 U.S. at 340 (quoting Melville B. NiMMER \& DAVID NIMMER, COPYRIGHT §§ 1.08[C][1], 2.01[A]-[B] (1990)).

72. See PosNeR, supra note 13, at 60; Horovitz, supra note 32 , at 257-58; Stearns, supra note 3, at 519.

73. See Stearns, supra note 3, at 519 .

74. See supra note 41 and accompanying text. 
the artist.

3. Plagiarism Is Not the Same As Following Techniques, Ideas, Methods, or Processes of Creation Under the IdeaExpression Distinction

Artists and designers reading copyright's requirements may be puzzled by the apparent disconnect with their own artistic training and education. Art training involves copyingone practices the lessons of the past by copying the works of the past. One demonstrates the development of artistic skills by showing that one can duplicate the works that exhibit these skills. Notably:

Although imitation is an inevitable component of creation, plagiarists pass beyond the boundaries of acceptable imitation by copying from the work of others without improving upon the copied material or fully assimilating it into their own work; by failing to attribute the copied material to its actual author; and by intending to deceive others about its origin. 75

In truth, there is no disconnect between the advice not to copy and the training an artist receives in arts education. There is only a clarification: works that an artist wants to copyright may not be copies of other works, and any works that are to be offered for sale or for any other personal benefit may not be copies of other works. ${ }^{76}$ This not only is advice for the ethical treatment of other artists, it also is legal advice for how to produce copyrightable works under the originality requirement and to avoid liability for copyright infringement. 77

75. Stearns, supra note 3 , at 520 .

76. It is possible that students might be required to complete an assignment for a grade in school that calls for them to copy certain works-for example, an assignment or portfolio requirement that contemplates submission of copied works to demonstrate the mastery of an artistic skill or the achievement of a certain level of performance. This practice does not implicate the copyright laws unless the students further attempt to promote themselves beyond the academic setting using the copied works or if they attempt to sell or license the copied works outright. See supra notes 34-37 and accompanying text. In addition, I am not suggesting that plagiarized works or copied works in general are uniformly acceptable as student work product in academic settings; in general, plagiarized works would not be acceptable and would constitute an academic violation. Students must be careful to know and understand the requirements of their department and institution regarding the copying of works for academic assignments.

77. See generally LeOnard D. DuBoff, Michael D. MurRay \& Christy KING, THE DESKBoOK OF ART LAW, Booklet P 86-87 (2010) [hereinafter DuBoff, Murray \& King, Deskbook of ART LAw]; LeONARD D. DuBofF, 
On the other hand, nothing prevents an artist or designer from learning from and employing other people's artistic ideas, techniques, methods, or processes of creation. As discussed above, the idea-expression distinction in copyright law allows ideas to be exploited, ${ }^{78}$ not works (expressions of ideas). ${ }^{79}$ The concept of "ideas" in copyright law encompasses techniques, methods, procedures, and processes; thus an "idea," even a technique or method of creation, can be copied, but not the works themselves (expressions of the idea) produced using the technique or method of creation. ${ }^{80}$ This is a significant distinction regarding copyright law and the other intellectual property protections of patent and trade secret law which protect inventions and innovations. 81

An illustration is in order: glass artist A and glass artist B both work as gaffers (glass blowers and shapers) in the studio of master glass artist C. Glass artists A and B both study the methods and techniques of glass blowing and glass shaping used by the master artist $\mathrm{C}$, and from time to time, they individually execute and create the glass sculptures conceived of and designed by the master artist. After several years, both $\mathrm{A}$ and $\mathrm{B}$ decide to go out on their own and produce their own glass sculptures. A uses the techniques learned on the job to execute and create A's own conceptions and designs for glass sculpture, and A produces works that are fully copyrightable and do not infringe on master artist C's works because A did not attempt to copy any of C's works. ${ }^{82} \mathrm{~B}$, on the other hand,

SHERri BurR, \& MichaEL D. MURRAY, ART LAW ch. 2 (Aspen 2010) [hereinafter DUBOFF, BURR \& MURRAY, ART LAW].

78. See 17 U.S.C. § 102(b) (2006); Harper \& Row Publishers, Inc. v. Nation Enters., 471 U.S. 539, 556 (1985).

79. See Golan v. Holder, 132 S. Ct. 873, 890 (2012); Eldred v. Ashcroft 537 U.S. 186, 219 (2003); Feist Publ'ns, Inc. v. Rural Tel. Serv. Co., 499 U.S. 340, 349-50 (1991); Harper \& Row, 471 U.S. at 556.

80. See 17 U.S.C. $\$ 102(b)$ (2006); see also supra note 79.

81. See Bilski v. Kappos, 130 S. Ct. 3218, 3225 (2010) (discussing patents); Dastar Corp. v. Twentieth Century Fox Film Corp., 539 U.S. 23, 34 (2003) (discussing trademarks).

82. This scenario intends to focus attention on the copyright issues presented by the idea-expression distinction and the fact that artistic methods, techniques, processes, and procedures are not subject to copyright. It is possible that this scenario could implicate other rights of master artist $\mathrm{C}$, such as a potential trade-secret right, or it could implicate an employee confidentiality agreement or covenant not to compete agreement between the employer and the two employees of this scenario, if such an agreement were in place between the parties. In theory, $\mathrm{C}$ might have patented one or more of the 
sought to gain some attention and obtain a leg up in the glass art world by going out of his way to use the techniques B learned in C's studio to produce works that closely resemble C's works. Because B is skillful at glass blowing and because B set out to copy C's works, B's works duplicate C's works and are often confused with C's works at art shows and in galleries. B's works may well be held to be copies of C's works, and thus unoriginal and not copyrightable, and may further subject B to liability for copyright infringement of C's copyrighted works.

The purpose of this illustration is to show that artistic training in the processes and procedures of other artists is necessary and expected, and does not lead to copyright infringement unless and until the trained artist decides to employ the acquired skills to duplicate or even to closely mimic the works of other artists. ${ }^{83}$

Mimicry deserves special attention. On the one hand, copyright law protects original artists from those who would seek to mimic the works of the artists through the copyright derivative works right owned by the copyright owner of the work. ${ }^{84}$ On the other hand, the idea-expression dichotomy, discussed above, allows artists to create works that follow the same formula, genre, or technique as the works produced by earlier artists. The ethical, plagiaristic difference is one of intent while the legal, copyright law difference is one of result.

In plagiarism, as exhibited by artist $\mathrm{B}$ in the illustration above, the second artist sought to make her works appear the same as master artist C's works. It was not simply a resemblance caused by the two artists working in the same medium using similar techniques. This mimicry was intended

processes and procedures used in C's studio, in which case neither A nor B would automatically be entitled to employ the patented procedure in the creation of their own glass works. The successful patenting of an artistic process would be the exception, not the rule; it would be much more likely that $\mathrm{C}$ did not obtain a patent and that $\mathrm{A}$ and $\mathrm{B}$ would have the ability to use all of the non-patented artistic procedures on their own outside of their employment with $\mathrm{C}$ absent a trade secret or employment agreement restriction that prevents it.

83. See, e.g., Harper \& Row, 471 U.S. at 547-49; see also Nichols v. Universal Pictures Corp., 45 F.2d 119, 121 (2d Cir. 1930) (explaining that infringement becomes increasingly possible as the level of abstraction becomes more concrete, and more detail is shared between the original and the alleged infringing copy).

84. 17 U.S.C. $§ 106(2)(2006)$. 
to cause confusion in the audience for the works, the confusion being that B's works were produced by C. In copyright law, the derivative works right affords the owner of the copyright to the original work the right to make or authorize the creation of all adaptations, alterations, translations, and conversions of the original work into new works. ${ }^{85}$ It protects the original owner from copyists who seek to produce noticeably similar works based on the first work, but who make a few variations and do not exactly duplicate the first work; 86 the copyist need only take a portion of the desirable features (more than a trivial amount, but not necessarily the heart) of the original work to be guilty of copyright infringement for creating an unauthorized derivative work. 87 Infringement by the creation of a derivative work does not require proof of a certain mental state, but the law will attempt to make distinctions between innocent practitioners of the same genre, medium, or art form, whose works share some resemblance, and those who produce substantially similar looking works that replicate a portion of the desirable features of the original work. In a perfect world, it would be obvious and effortless to discern who had copied and who had simply followed similar techniques common to the medium or genre of art. In reality, attorneys will solicit proof that the artist followed completely innocent practices of creation, or questionable practices of mimicry and outright plagiarism. Thus, when the inquiry may eventually reach into the artist's process of creation-What inspired this work when you created it? Were you thinking of another work at that time? Did you look at other works by other artists at that time?- the advice remains not to set out to copy other artists' works in the first place.

Innocently following the method and techniques of a certain school or genre of art will sometimes result in two artists producing works that are similar to each other. This kind of accidental similarity is accepted and permitted under

85. Id.; see also Stewart v. Abend, 495 U.S. 207, 220-21 (1990); cf. Harper \& Row, 471 U.S. at 549-50.

86. Harper \& Row, 471 U.S. at 547-49; Nichols, 45 F.2d at 121.

87. Harper \& Row, 471 U.S. at 564-66; Nichols, 45 F.2d at 121. Compare Hoehling v. Universal City Studios, Inc., 618 F.2d 972, 974 (2d Cir. 1980), with Wainwright Securities Inc. v. Wall Street Transcript Corp., 558 F.2d 91 (2d Cir. 1977). This is a comparison suggested by the Supreme Court in Harper \& Row, 471 U.S. at 549-50. 
copyright law as long as the similarity is "fortuitous, not the result of copying." 88 Although the concept of accidental similarity is known and accepted as a possible occurrence outside of situations of copying, in cases of substantial similarity or near-exact-similitude between two works of two different artists, it may be difficult for the second artist to convince a court that the similarity was fortuitous, and not the product of copying. If the second artist had no ability to see or access the first work, the argument becomes much stronger. If the second artist never looks to copy or mimic the works of other artists, the argument practically speaking will be unnecessary; the likelihood that the second artist will innocently and accidentally replicate another artist's works to the degree of substantial similarity or near-exact-similitude that would bring a copyright infringement claim to bear is negligible.

The copyright law doctrines of merger and scènes à faire also allow for similarity arising from the common subject matter of two different artists' works, ${ }^{89}$ as where the two artists both attempt to depict the same scene or real-world subject matter, such as by creating a realistic depiction of an animal, a flower, the Grand Canyon at sunrise, or a texture-free application of red acrylic paint on a square, flat canvas. The term, scènes à faire, roughly translates to "scenes that must be done"-an "obligatory scene" with necessary elements of depiction required in order to communicate the meaning of the depiction to an audience. ${ }^{90}$ For ethical artists and designers, the concept means that similarity between two works that is caused by the requirements of a successful, meaningful depiction of the same subject matter is acceptable, while similarity caused by one artist's copying of the other artist's

88. Feist Publ'ns, Inc. v. Rural Tel. Serv. Co., 499 U.S. 340, 345 (1991).

89. NIMMER \& NIMMER, supra note 38, § 13.03[B][4]; see also Kurtz, supra note 38 , at $79,86,89-91$ (arguing that authors build from their predecessors); Lichtman, supra note 38, at 734-39 (stating that under the merger doctrine, copyright protection is denied when there are only a few ways to express an idea to prevent monopolization of the market); Mtima, supra note 38, at 9499; Copyright Originality, supra note 33, at 784-99.

90. NIMMER \& NiMMER, supra note 38, § 13.03; Kurtz, supra note 38, at 86, 89; see also Eva E. Subotnik, Originality Proxies: Toward a Theory of Copyright and Creativity, 76 BROOK. L. REV. 1487, 1542-44 (2011) (describing court interpretations of stock imagery). 
work is not. ${ }^{91}$ Only the points of similarity directly attributable to the subject matter are excusable; each artist can protect their individual artistic rendition and embellishments that exceed the points of similarity dictated by the subject matter. ${ }^{92}$ Once again, it might come down to a matter of proof, and having an honest account of choosing a certain subject matter and producing the depiction without reference to the work of any other artist who also depicts this subject matter will put an artist on a strong footing.

Similarity that is traced to a method of production and not to an act of copying also is protected by the originality doctrine. ${ }^{93}$ Artists cannot obtain a "copyright" over their artistic processes and procedures, and other artists are free to observe, adapt, reverse-engineer, and employ even the most innovative processes and procedures for the creation of original art without running afoul of the copyright laws. ${ }^{94}$ Thus, copyright does not set a trap for students receiving traditional artistic training in art schools, university departments, and studios that threatens to turn each project they work on using the skills they have learned from other artists into a continuous process of copyright infringement.

4. The Parallels of Plagiarism and the Exploitation of a Celebrity's Name, Image, or Likeness

Exploitation through plagiarism parallels the concept of exploitation through misuse of a celebrity's name, image, or likeness in right of publicity law. As discussed above, the prohibitions parallel each other, but they do not overlap completely, because the benefits gained by a copyist from the exploitation of a celebrity's persona generally are not selfaggrandizing benefits such as professional or academic credit. ${ }^{95}$ Artists and designers exploit celebrities for the attractive power

91. See Subotnik, supra note 90, at 1543 (arguing that there is an underlying idea of fairness in using things within the public domain).

92. Id. at 1544 (noting that photographers often use the same subject but produce different depictions of that subject).

93. 17 U.S.C. $\S 102(b)(2006)$.

94. See supra note 83 . There is a possibility that the artist would run into a trade secret, employment agreement, or patent law issue, but not a copyright issue-unless the second artist copied the actual works of the first artist. 17 U.S.C. $\S 102(b)$ (2006) (exempting processes and procedures from copyrightability).

95. See supra notes 17, 19, 68 and accompanying text. 
of their name and image or for the symbolic, expressive power of their persona, but rarely in a manner that causes the public to confuse the celebrity's attributes with the attributes of the artist or designer. Nevertheless, right of publicity law prohibits uses of a celebrity's persona that are self-serving and that constitute unfair and unethical exploitation, providing the connection with the ethical prohibition on plagiarism. ${ }^{96}$

The advice not to copy other people's works under copyright law extends to the use of a celebrity's name, image, or likeness under right of publicity law: if you want to remain ethical and liability-free, do not use other people's names, images, or likenesses in your art. If you find yourself compelled to use a celebrity name, image, or likeness, carefully follow the advice and recommendations here that explain the difference between expressive, creative uses that require the use of the celebrity's identifiable and recognizable attributes, and uses that amount to crass exploitation of the star-power of the celebrity.

The right of publicity is a right to control the use of one's name, image, likeness, or other valuable attributes of one's persona by others, when others seek to use these things for personal gain or commercial advantage. ${ }^{97}$ The right of publicity typically is classified as an intellectual property right98_ "the inherent right of every human being to control the commercial use of his or her identity." 99 While there are many connections and overlapping features of publicity rights and other intellectual property rights (particularly copyright), there are also differences, and artists and designers should alert themselves to these differences.

In the case of copyright and the right of publicity, not all of the requirements and public policies supporting the two rights

96. See supra note 66 and accompanying text.

97. See, e.g., CAL. CIV. CODE $§ 3344$ (West 1997); see also RESTATEMENT (THIRD) OF UNFAIR COMPETITION $§ 46$ (1995); PUBLICITY AND PRIVACY, supra note 65 , at $\S 3.2$.

98. Almeida v. Amazon.com, Inc., 456 F.3d 1316, 1322 (11th Cir. 2006) (stating that the right of publicity is an intellectual property right); see also, e.g., BLACK'S LAW DICTIONARY 881 (9th ed. 2009) (defining "intellectual property" as including publicity rights); J. Thomas McCarthy, Melville B. Nimmer and the Right of Publicity: A Tribute, 34 UCLA L. REV. 1703, 1712 (1987) ("The right of publicity [has] matured into a distinctive legal category occupying an important place in the law of intellectual property.").

99. ETW Corp. v. Jireh Publ'g, Inc., 332 F.3d 915, 928 (6th Cir. 2003). 
of action are the same. Further, defenses that are effective against one are not automatically effective against the other. For example, originality and creativity are not requirements for right of publicity protection 100 (for which many pop stars and celebrities of the moment should be grateful). Nevertheless, publicity rights are extended to persons to control or bar uses that exploit the value of their names, images, or likenesses in ways that exactly parallel the rights of the owners of original, copyrightable works. ${ }^{101}$ Copyright fair uses generally apply in right of publicity actions, but not exactly in a one-to-one correspondence that would allow for fairly simple legal analyses and straight-forward predictions regarding one kind of artistic use of a celebrity image compared to another. ${ }^{102}$

The right of publicity is complicated by a number of historical anomalies that led to a messy establishment of a right of action. One, the right was initially conceived of as a right of privacy claim, focusing on use of a name, image or likeness as being an intrusion into one's personal sphere, with resulting injuries to one's person (e.g., feelings, reputation, or standing in the community). ${ }^{103}$ Two, the right later morphed

100. See Stacey L. Dogan \& Mark A. Lemley, What the Right of Publicity Can Learn from Trademark Law, 58 STAN. L. REV. 1161, 1163-66, 1190 (2006) (arguing that similar to trademark law, the right of publicity is not concerned with the encouragement of new creation but protection of names and integrity in commercial contexts); Dougherty, supra note 66, at 27-28 (concluding that transformative works recognize separate value and creativity within the work, and transformative works do not violate the right of publicity); Michael Madow, Private Ownership of Public Image: Popular Culture and Publicity Rights, 81 CALIF. L. REV. 125, 134 (1993) (arguing that right of publicity is about determining the meaning of images); Steven Semeraro, Property's End: Why Competition Policy Should Limit the Right of Publicity, 43 CONN. L. REV. 753, 775-81 (2011) (arguing that right of publicity assists celebrities with maximizing profit).

101. See Haelan Labs., Inc. v. Topps Chewing Gum, Inc., 202 F.2d 866, 868 (2d Cir. 1953) (advancing publicity law away from privacy law, and holding publicity law protects the public value of a celebrity image); see also Marshall Leaffer, The Right of Publicity: A Comparative Perspective, 70 ALB. L. REV. 1357, 1360 (2007).

102. See infra Part III (describing fair uses in copyright and right of publicity law).

103. ETW, 332 F.3d at 952-53; PUBLICITY AND PRIVACY, supra note 65, § 1.11; see also Dogan \& Lemley, supra note 100, at 1167-71 (presenting a comprehensive history of the right of privacy); Samuel D. Warren \& Louis D. Brandeis, The Right to Privacy, 4 HARV. L. REV. 193, 195 (1890) (arguing that with the advancement in civilization, privacy requires a need for personal protection). 
into a property right claim, protecting the commercial value of a celebrity name, image, or likeness from unauthorized exploitation of that monetary value. ${ }^{104}$ Three, the right has never been tied to one set of public policy goals that would allow for a more orderly evaluation of the rights of publicity against other important rights, such as free speech and artistic expression. 105 This has an impact on the use of celebrity images and likenesses: it is considered less "fair" to use an image if the harm is characterized as a personal injury rather than simply a harm to a pecuniary or property right. Torts (i.e., personal injuries) usually are not excused simply because the actor had a motive to communicate. On the other hand, expression of news, social commentary, or education may be all that is required to balance out a use as "fair" compared to a person's pecuniary interest in their name, image, or likeness.

There are four public policies that support the extension of publicity rights: (1) direct reward to artists, performers, entertainers, and athletes for achievement in their areas; 106 (2) indirect support to artists, performers, entertainers, and athletes to encourage them to strive to excel so as to benefit the public at large with better arts, literature, entertainment, and sports (this being the exact public policy supporting the extension of copyright and patent intellectual property rights);107 (3) equitable considerations of fairness and prevention of unjust enrichment and unfair competition (which has more overlap with the policies supporting the trademark laws which seek to avoid consumer confusion and unfair

104. ETW, 332 F.3d at 952-53; Haelan, 202 F.2d at 866; W. PAGE KEETON ET AL., PROSSER AND KeETON ON THE LAW OF TORTS $§ 117$ (5th ed. 1984); Dogan \& Lemley, supra note 100, at 1170-73.

105. See Dogan \& Lemley, supra note 100, at 1172-73 (explaining that the court did not tie its decision to specific policy justifications rather than to a broader context).

106. Madow, supra note 100, at 205-17 (explaining various economic incentives that directly benefit artists); see also Mark Bartholomew, A Right Is Born: Celebrity, Property, and Postmodern Lawmaking, 44 CoNN. L. REV. 301, 310-14, 321-31 (2011) (arguing the importance of recognizing celebrity value).

107. Madow, supra note 100, at 206-09 (arguing that celebrities foster their talent to benefit society as a whole); Bartholomew, supra note 106, at 321-31 (arguing that celebrity's actions are for the public spotlight); see also Eldred v. Ashcroft, 537 U.S. 186, 246-47 (2003) (arguing that "authors" under copyright law are not the primary beneficiaries of the public benefits of the law). 
competition); 108 and (4) outright theft of something valuable and marketable that is referred to as good will, star power, or simply publicity value. ${ }^{109}$ Again, the fact that there are four policies makes the law complicated for attorneys, judges, and legislators seeking to interpret, apply, or advance the law, as well as for artists and designers seeking to walk a safe path under the law, because the public policies do not always argue in favor of the same extension of rights and the same defenses against the rights. Artistic expression is regarded as a worthy activity, but it carries less force when weighed in a consideration of equity (the artist took for free what others regularly pay for), rather than in a balancing of one public good (encouragement of celebrities and athletes to improve their craft and sport for the good of the public) against another (free, uninhibited expression of the meaning, message, role, or function of the celebrity or athlete in the modern world for the good of the public). The analysis returns to the purpose of the activity and whether, on balance, it appears to promote First Amendment values, or whether it amounts to exploitation.

Exploitation in the right of publicity context, as in plagiarism, requires an artist to use the celebrity's name, image, or likeness for some advantage. The public policies behind right of publicity law have converged to require that the advantage must be one that benefits the user in a manner that does not directly serve First Amendment values of commentary, criticism, news reporting, and education of public affairs. ${ }^{110}$ In other words, the artist's or designer's purpose-

108. Carson v. Here's Johnny Portable Toilets, Inc., 698 F.2d 831, 838 (6th Cir. 1983); C.B.C. Distribution \& Mktg., Inc. v. Major League Baseball Advanced Media, L.P., 443 F. Supp. 2d 1077, 1090 (E.D. Mo. 2006), aff'd, 505 F.3d 818 (8th Cir. 2007); RESTATEMENT (THIRD) OF UNFAIR COMPETITION $§ 46$ cmt.c (1995); Roberta Rosenthal Kwall, Property and Liability Rule Analysis, 70 IND. L.J. 47, 54-55 (1994).

109. See C.B.C. Distribution, 443 F. Supp. 2d at 1090 (arguing that dilution of a person's identity might occur).

110. H. Lee Hetherington, Direct Commercial Exploitation of Identity: A New Age for the Right of Publicity, 17 ColuM.-VLA. J.L. \& ARTS 1, 15-16, 2023 (1992); Daniel E. Wanat, Entertainment Law: An Analysis of Judicial Decision-Making in Cases Where a Celebrity's Publicity Right Is in Conflict with a User's First Amendment Right, 67 ALB. L. REV. 251, 271-77 (2003); see also ETW Corp. v. Jireh Publ'g, Inc., 332 F.3d 915, 955 (6th Cir. 2003) (identifying the tension between the right of publicity and First Amendment Rights); Comedy III Prods., Inc. v. Gary Saderup, Inc., 21 P.3d 797, 803-08 (Cal. 2001). 
her predominant purpose 111 -in using the celebrity's persona must be self-serving in greater proportion than the service paid in First Amendment activities that substantially benefit the public. ${ }^{112}$ The need to accommodate First Amendment concerns causes the courts to concentrate heavily on the artist's predominant purpose in using the celebrity name, image, or likeness. To be sure, not every expressive use of a celebrity's persona is predominantly expressive in a way that benefits First Amendment concerns more than the concerns over the exploitation of the celebrity star power. Many expressive uses are held to be predominantly self-serving and exploitative. Newspapers, television broadcasters, bloggers, artists, or designers want to be known for good works, increase their following, increase sales of the newspaper or advertising revenues on the blog or broadcast, or simply increase their own stature in their community; however, the law accepts these pecuniary advantages and focuses instead on the predominant purpose of the activity and whether, on balance, the activity fulfills First Amendment goals and public policies over any collateral exploitation at work in the case. ${ }^{113}$

The advantage may be as obvious as trying to market or advertise one's own artworks using the celebrity's name, image, or likeness as an attention-getter or simply to suggest some kind of approval (e.g., sponsorship, endorsement) by the celebrity of the artist's works. An unauthorized "advertising" use would certainly run afoul of the publicity laws.114 But it

111. I use the term, "predominant purpose," in part because the case law gravitates to this term. See, e.g., ETW, 332 F.3d at 959; Winter v. DC Comics, 69 P.3d 473, 478 (Cal. 2003); Comedy III, 21 P.3d at 809; Doe v. TCI Cablevision, 110 S.W.3d 363, 374 (Mo. 2003) (en banc). The law recognizes that multiple purposes for use of a name, image, or likeness most often are at play in the activity.

112. ETW, 332 F.3d at 955-59; Cardtoons, L.C. v. Major League Baseball Players Ass'n, 95 F.3d 959, 968-72 (10th Cir. 1996); Winter, 69 P.3d at 478; Comedy III, 21 P.3d at 806-09; Doe, 110 S.W.3d at 370-74.

113. Compare ETW, 332 F.3d at 959 (arguing for a predominantly expressive purpose in a painting and serigraph series that depicted several scenes from Tiger Woods' historic first winning of the Masters major golf tournament), with Zacchini v. Scripps-Howard Broad. Co., 433 U.S. 562, 56978 (1977) (demonstrating the power of the right of publicity when the Court failed to uphold the First Amendment rights of a television news broadcaster that aired the public interest news information about a county fair performer and exploited the performer's human cannonball act); see also Winter, 69 P.3d at 478; Comedy III, 21 P.3d at 809; Doe, 110 S.W.3d at 374.

114. See, e.g., Hilton v. Hallmark Cards, 599 F.3d 894, 909-1005 (9th Cir. 
could be a use of the celebrity's name, image, or likeness simply to improve the quality, content, and value of the works themselves, as in the case where an artist's paintings of generic golfers do not sell, but the artist's paintings of an instantly recognizable Tiger Woods sell like hotcakes. Even though expressive use of the image has First Amendment value, the use might be viewed as an unfair advantage taken by the artist that amounts to a violation of Woods' right of publicity. ${ }^{115}$ The advantage to the artist need not be large. If the artist has a purpose and intention in mind that obviously exceeds mere exploitation of the celebrity's star power, the use of the celebrity's name, image, or likeness may be approved as a "fair use" as discussed in the next Part.

\section{MODIFY IT OBVIOUSLY-THE ETHICS OF TRANSFORMATION OF COPYRIGHTED WORKS OR CELEBRITY IMAGES OR LIKENESS}

The doctrine of fair use in copyright law was created and developed to further the same goals as the constitutional protection of copyrights and patents: "To promote the Progress of Science and useful Arts," 116 as well as to protect the constitutional First Amendment goals of open and robust free expression.117 Fair use is one of the main reasons why the Supreme Court holds that the copyright monopoly on replication of copyrighted works does not violate the First Amendment's limits on content-based restraints of expression. ${ }^{118}$ The value of writings and creations to the

2010); Toffoloni v. LFP Publ'g Grp., 572 F.3d 1201, 1213 (11th Cir. 2009); Abdul-Jabbar v. General Motors Corp., 85 F.3d 407, 416 (9th Cir. 1996); Midler v. Ford Motor Co., 849 F.2d 460, 462 (9th Cir. 1988); Bosley v. Wildwett.com, 310 F. Supp. 2d 914, 920 (N.D. Ohio 2004); Doe, 110 S.W.3d at 373-74.

115. But see ETW, 332 F.3d at 959 (arguing that the artist balanced the expressive purpose over the exploitative purpose in the depiction of scenes from Tiger Woods' historic first winning of the Masters major golf tournament).

116. U.S. ConsT. art. I, $\S 8$, cl. 8.

117. U.S. ConsT. amend. I; see also Whitney v. California, 274 U.S. 357, 375, 377 (1927) (Brandeis, J., concurring) (arguing against repression of speech); Abrams v. United States, 250 U.S. 616, 630 (1919) (Holmes, J., dissenting) (arguing for the free trade of ideas).

118. Eldred v. Ashcroft, 537 U.S. 186, 246-47 (2003); Harper \& Row Publishers, Inc. v. Nation Enters., 471 U.S. 539, 547-50 (1985). 
progress of science and the arts is that they are new-not copied-and therefore, "original." The creation and promulgation of new expression also is a core objective of the First Amendment.119 Thus, the ethical use and treatment of existing works is intended to further the creation of new, alloriginal content or obviously modified content. "Obviously modified content" is new expression, not the same as the original. And like the copyright originality standard itself, modification and transformation do not require uniqueness or one-of-a-kind status, but they do require new expression.

Fair use always has involved the examination of the user's motive: Was it to steal or to create? Was it to avoid the drudgery of thinking up original works, or was it to build on works through obvious transformation so as to create "something new, with a further purpose or different character, altering the first with new expression, meaning, or message"? 120 A more succinct question is, was the motive to be expressive or exploitative? Thus, the concepts of transformation and predominant purpose dominate the discussion of copyright fair use. ${ }^{121}$

Right of publicity fair uses also are drawn directly from First Amendment freedom of expression principles. ${ }^{122}$ The recognized defenses are: comment and criticism, artistic expression, news reporting of newsworthy events, and advertising and promotion of the speaker's activities relating to one of the above uses. ${ }^{123}$

119. Golan v. Holder, 132 S. Ct. 873, 889-91 (2012); United States v. Stevens, 130 S. Ct. 1577, 1584-86 (2010).

120. Campbell v. Acuff-Rose Music, Inc., 510 U.S. 569, 579 (1994).

121. See What is Transformative?, supra note 39, at 1-3 (discussing the convergence of transformation and predominant purpose within copyright law).

122. See, e.g., Hilton v. Hallmark Cards, 599 F.3d 894, 909-10 (9th Cir. 2010) (discussing the use of the transformative test and public interest defense, both grounded in First Amendment principles); C.B.C. Distribution \& Mktg., Inc. v. Major League Baseball Advanced Media, L.P., 505 F.3d 818, 819 (8th Cir. 2007); Comedy III Prods., Inc. v. Gary Saderup, Inc., 21 P.3d 797, 809 (Cal. 2001) (discussing the application of First Amendment to the publicity context of baseball cards).

123. See, e.g., RESTATEMENT (THIRD) OF UnFAIR COMPETITION $§ 47 \mathrm{cmt}$. c (1995); DuBofF, MurRaY, \& King, DeskboOK OF ART LAW, supra note 77, at Bk. S; DuBofF, BurR, \& MURRAY, ART LAW, supra note 77, at ch. 5; see also ETW Corp. v. Jireh Publ'g, Inc., 332 F.3d 915, 935-36 (6th Cir. 2003) (defending works of artistic expression); Winter v. DC Comics, 69 P.3d 473, 
In spite of its different origins in the law, right of publicity law recognizes the two steps of transformation and predominant purpose directly in its fair use analyses. The transformative requirement is met by the alteration of the content, meaning, and expression-in short, the value-of the image, likeness, or name of the celebrity used in the second work. ${ }^{124}$ A work that copies or allows the celebrity publicity value of the image, likeness, or name (the same meaning, same expression, same purpose, for the same audience) to shine through in the artist's work will not be deemed to be fair. ${ }^{125}$ Another, less-strictly-defined path to the same determination is to consider whether the second work's predominant purpose is to exploit the celebrity publicity value of the name, image, or likeness, or whether it has a predominantly expressive purpose adding new, expressive value to the original name, image, or likeness. ${ }^{126}$

\section{A. TRANSFormation With a PREDOMINANT FiRst AMENDMENT EXPRESSIVE PURPOSE IN COPYRIGHT FAIR USE LAW}

I have written elsewhere about the convergence of transformation and predominant purpose analysis in copyright fair use law. ${ }^{127}$ Campbell established that "transformation" requires a change in the purpose and character of the work.128 It is evident from the record of cases that the courts take the "purpose" part of that interpretive rule very seriously, for all of the approved fair uses in the appellate cases involved a change in the predominant purpose for the use of the work rather than simply a change in the character (the form, the contents) of the

478 (Cal. 2003); Matthew D. Bunker, Free Speech Meets the Publicity Tort: Transformative Use Analysis in Right of Publicity Law, 13 COMM. L. \& POL'Y 301, 304-20 (2008); Garon, supra note 41, at 485-92; Andrew Koo, Right of Publicity: The Right of Publicity Fair Use Doctrine-Adopting a Better Standard, 4 BUFF. INTELL. PROP. L.J. 1, 18-23 (2007).

124. See, e.g., Hilton, 599 F.3d at 909-10; Hart v. Electronic Arts, Inc., 740 F. Supp. 2d 658, 665 (D.N.J. 2010); Romantics v. Activision Publ'g, Inc., 574 F. Supp. 2d 758, 770 (E.D. Mich. 2008) (discussing the distinctiveness of products and potential confusion by consumers).

125. Hilton, 599 F.3d at 909-10; Comedy III, 21 P.3d at 800.

126. ETW, 332 F.3d at 959; Winter, 69 P.3d at 478; Comedy III, 21 P.3d at 809; Doe v. TCI Cablevision, 110 S.W.3d 363, 374 (Mo. 2003) (en banc).

127. What is Transformative?, supra note 39, at 1-3.

128. Campbell v. Acuff-Rose Music, Inc., 510 U.S. 569, 579 (1994). 
work. 129

There are three successful pathways to fair use in copyright law:

- Transformation of content of the work with a change in the predominant purpose of the work ${ }^{130}$

- Transformation of the context of the work with a change in the predominant purpose of the work ${ }^{131}$

- A significant change in the predominant purpose and function of the work even without a change in the content or context of the work. ${ }^{132}$

The strongest transformative fair uses are those that modify the contents, function, and purpose of the original work in a significant and obvious manner, by turning the meaning of the work on its head, or by openly criticizing the original work. ${ }^{133}$ Ideally, the expression of the contents of the original work is altered ${ }^{134}$ or overwhelmed by the addition of significant creative expression 135 so that the predominant purpose of the new work is significantly different from that of the original work. 136 This is the most secure path to fair treatment of other artists' works, which is why the recommendation of this Article

129. What is Transformative?, supra note 39, at 5; see also Perfect 10, Inc. v. Amazon.com, Inc., 508 F.3d 1146, 1165 (9th Cir. 2007) (holding that Google's use of thumbnails in search engines is highly transformative); Blanch v. Koons, 467 F.3d 244, 248-50 (2d Cir. 2006) (holding that transformative use requires more than finding a new way to exploit the original work); Suntrust Bank v. Houghton Mifflin Co., 268 F.3d 1257, 1269 (11th Cir. 2001).

130. See generally What is Transformative?, supra note 39, at 274-95.

131. Id.

132. Id. In this recent work, I examine all of the United States Supreme Court and United States Court of Appeals cases applying the transformative test to evaluate copyright fair use claims in every type of copyrightable media. In the instant article, I focus my discussion on the data set of cases synthesized in the prior article that involve artistic works and cases involving certain fair use defenses, such as parody, that are well-suited for application in art and design situations.

133. Campbell, 510 U.S. at 579 (stressing the importance of altering the purpose of images); Blanch, 467 F.3d at 251-53; Mattel Inc. v. Walking Mountain Prods., 353 F.3d 792, 800-02 (9th Cir. 2003); Suntrust Bank, 268 F.3d at 1269 .

134. Campbell, 510 U.S. at 579; Suntrust Bank, 268 F.3d at 1257, 1269; Leibovitz v. Paramount Pics. Corp., 137 F.3d 109, 109 (2d Cir. 1998).

135. Blanch, 467 F.3d at 251; Mattel, 353 F.3d at 800-02.

136. Campbell, 510 U.S. at 569; Perfect 10, Inc. v. Amazon.com, Inc., 508 F.3d 1146, 1164 (9th Cir. 2007); Blanch, 467 F.3d at 251; Suntrust Bank, 268 F.3d at 1269 . 
is that if artists or designers intend to incorporate material from preexisting works into their own works, they should modify the material in an obvious manner.

The use of an artistic original work will be deemed transformative when the use adds valuable artistic changes to the original giving the resulting work new meaning and artistic expression. ${ }^{137}$ The artistic changes must create a new meaning and new expression; if the original simply is redisplayed, reproduced, rebroadcast, or redistributed in a new mode or method of exploiting the same creative artistic virtues of the original work, the use will be deemed not to be transformative, and not to be a fair use. ${ }^{138}$ This point is significant for artists

137. See Campbell, 510 U.S. at 577-80 (discussing how the rap group added new musical style and genre and new lyrics to original rock ballad creating a new musical composition with a new, cynical, streetwise meaning); Blanch, 467 F.3d at 244 (examining how artist Jeffrey Koons placed Blanch's original fashion magazine photographic image into painting combining image with additional "images of confections" and Niagra Falls to make a new expression commenting on the appetites of modern society); Leibovitz, 137 F.3d at 109 (examining how a movie poster changed original Leibovitz photograph from a work of serious art with a historical Renaissance art reference to one with a new parodic meaning)

138. Murphy v. Millennium Radio Grp. L.L.C., 650 F.3d 295, 307 (3d Cir. 2011) (concluding the slightly cropped photo of radio "shock jocks" used for the same news and promotional purposes as the original photo was not transformative, and therefore not fair use); Bouchat v. Balt. Ravens Ltd., 619 F.3d 301, 309 (4th Cir. 2010) (plaintiff Bouchat's Shield Drawing was adapted for the Raven's "Flying B" logo on helmets and uniforms, on the playing field, and in posters, tickets, and advertising, but all such uses as a logo still revealed and reproduced the same valuable artistic expression as the original Shield Drawing, and the product of the changes and adaptations still carried the same meaning and message as the original); Gaylord v. United States, 595 F.3d 1364, 1372-73 (Fed. Cir. 2010) (concluding the photograph and postage stamp depicting plaintiff's Korean War Memorial each adapted and altered the appearance of the war memorial to display a different tone and mood in the depiction, but the ultimate meaning and message of the original memorial and these artistic adaptations was held to be the same: to remember and celebrate Korean War Veterans; thus, the uses were not fair); Bridgeport Music, Inc. v. UMG Recordings, Inc., 585 F.3d 267, 278 (6th Cir. 2009) (affirming that although defendant's sampling placed the iconic Atomic Dog funk lyric and funk track in an updated hip-hop recording, the most recognizable elements of the funk track were reproduced with little variation or alteration from the original; thus, the track was reused for the same musical artistic purposes as the original, and the hip-hop version of the sample carried the same meaning and expression as the original; therefore, the use was not fair); Castle Rock Entm't, Inc. v. Carol Publ'g Grp., 150 F.3d 132, 142 (2d Cir. 1998) (changing the format and medium of entertainment material from the Seinfeld television series to a trivia quiz format did not add new and valuable artistic or entertainment content to the original material, 
and designers because it often is the case that artists and designers will seek to incorporate preexisting works into their works precisely to show off the valuable aesthetic attributes of the preexisting work. Artists want to recast the works in a new setting, but allow the original art and imagery to shine through in their new work; musicians want to take an attractive piece of an earlier recording and loop it continuously to show off its attractive elements. The motivation to reproduce attractive works to benefit the quality and attractiveness of the artist's own works is understandable, but the cases confirm that this kind of plagiaristic exploitation is unfair and unacceptable.

Works that are not changed in form ${ }^{139}$ may be transformed in predominant purpose by recontextualization of the copied material. 140 In successful cases, the new context contains additional expression that overwhelms the initial expression and prevents the original material from shining through in the new work for the same purposes for which the original work was created. ${ }^{141}$ A change in context for an artistic work even without any changes to the content of the work may be

and did not change the meaning, message, expression, or purpose of the original material; thus, the use of the original entertainment content was not fair)

139. I have evaluated changes in form to mean more than a change in size or reorientation of the material on a new axis. Certain cases involved a change in size of the works from full-scale to thumbnail size. See, e.g., Perfect 10, 508 F.3d at 1164; Bill Graham Archives v. Dorling Kindersley Ltd., 448 F.3d 605, 613 (2d Cir. 2006). Others took preexisting works and reoriented them on the axis of the work from diagonal to straight vertical. See e.g., Blanch, 467 F.3d at 247-49. Nothing in the law or cases indicates that this alteration alone is meaningful to a fair use analysis. However, as discussed previously, in each of these cases, the recontextualization of the material along with a change in the predominant purpose and functioning of the material was significant in making a successful determination of fair use in each case.

140. See Blanch, 467 F.3d at 248 (stating that artist Jeffrey Koons changed the function and purpose of Blanch's fashion photograph by recontextualizing it with a large array of images of "confections"); Mattel, 353 F.3d at 802-03 (explaining that the artist changed the function and purpose of a depiction of Barbie by recontextualizing the image into scenes with kitchen appliances).

141. Blanch, 467 F.3d at 248 (explaining that the plaintiff's photography was only one part of the imagery of women's legs shown, and whose expression was further changed by its juxtaposition with images of "confections" in Koons' work); Mattel, 353 F.3d at 802-03 (arguing that the artist changed the function and purpose of a depiction of Barbie by recontextualizing the image into scenes of seemingly dangerous kitchen appliances, thus changing the meaning and purpose from a depiction of the "ideal American woman" to an image of a frazzled or oblivious female in peril). 
sufficient if the predominant purpose and functioning of the new work is sufficiently different from the original work and fulfills one of the principle goals of the copyright laws. ${ }^{142} \mathrm{~A}$ change in context alone for artistic works is not necessarily sufficient if the change does not have a new purpose and function that communicates a new meaning with new, valuable expression, furthering a goal of the copyright laws. ${ }^{143}$

142. See Bouchat, 619 F.3d at 319-20 (explaining that the use of original Shield Drawing in logos held and displayed for historical and archival reasons at the Baltimore Ravens' headquarters was a use with a purpose and function different from the artistic purpose and meaning of the original work, and therefore holding that historical, referential, and archival uses are appropriate fair use purposes); Perfect 10, 508 F.3d at 1146, 1165 (holding that although the original photographs were reduced in size to thumbnail images but otherwise reproduced verbatim, the purpose and function of the thumbnails within an internet search engine's "image search" results screen was a completely new function with a new and different purpose and meaning from the artistic purposes and meaning of the original photographs; the use fulfilled proper fair use reference and research purposes); see also Bill Graham Archives, 448 F.3d at 609-10 (holding that while the original images of concert posters were reduced in size but otherwise reproduced verbatim, the purpose and function of the new use of the images - to document a timeline of concert performances of the Grateful Dead-was completely new and different from the artistic purposes and meaning of the original poster images and fulfilled proper fair use archival, historical, referential, and educational purposes); Kelly v. Arriba Soft Corp., 336 F.3d 811, 818 (9th Cir. 2003) (recognizing the use of original images in reduced size for purposes of displaying search results in internet image search engine was a new function with a new purpose and meaning); Núnez v. Caribbean Int'l News Corp., 235 F.3d 18, 22-23 (1st Cir. 2000) (concluding that the republication of original modeling portfolio photographs without alteration but within new context of news reporting of the actual existence of the photographs themselves after subject became Puerto Rico's Miss Universe contestant was a new function with a new meaning and new purpose for the photographs that met fair use news and reference purposes); Sony Computer Ent. America, Inc. v. Bleem, L.L.C., 214 F.3d 1022 (9th Cir. 2000) (using screen shots from original computer game in comparative advertising to critique the original images was fair use).

143. Bouchat, 619 F.3d at 309 (concluding that aside from historical and archival uses at Baltimore Ravens' headquarters, the general use of the plaintiff's Shield Drawing in stadium advertising, on the field, on uniforms, on tickets and other merchandise did not represent a new appropriate function for the drawing and did not fulfill a different artistic or creative purpose for the original work, and thus, did not constitute a fair use); Gaylord, 595 F.3d at 1372-73 (determining that the function and meaning of the original sculpture and the images in the photograph and postage stamp were held to be the same: to celebrate and remember Korean War Veterans); Leadsinger, Inc. v. BMG Music Publ'g,, 512 F.3d 522, 530 (9th Cir. 2008) (concluding that change in form and function from audio recording to karaoke soundtrack audio recording was not a new function carrying new meaning or purpose from original musical recordings); see also Zomba Enters., Inc. v. Panorama 
Parody is an excellent fair use because it uses the original work in order to ridicule the original work; the second user turns the function and purpose of the original work on its head, and in fact employs the expression of the original material in an effort to undermine the purposes and objectives of the original work. ${ }^{144}$ Satirical uses (i.e., uses for comment and

Records, Inc., 491 F.3d 574, 582-83 (6th Cir. 2007) (concluding that the change from an audio recording to a karaoke soundtrack audio recording was not a new function carrying new meaning or purpose from original musical recordings); Elvis Presley Enters., Inc. v. Passport Video, 349 F.3d 622, 628 29 (9th Cir. 2003) (holding that video and audio segments from performances of Elvis were recombined into a new context-a comprehensive video biography work-but were reproduced for the same purpose and carried the same function and meaning as the original video and audio recordings); Video Pipeline, Inc. v. Buena Vista Home Entm't, Inc., 342 F.3d 191, 198-200 (3d Cir. 2003) (copying two-minute segments of original motion pictures for use as internal reference for proprietary video database did not create a new function carrying a new appropriate fair use meaning and purpose different from the original artistic works); On Davis v. The Gap, Inc., 246 F.3d 152, 175-76 (2d Cir. 2001) (depicting the original artwork in a print ad was simply a new context for the work without any change in artistic purpose and function of the original work); A\&M Records, Inc. v. Napster, Inc., 239 F.3d 1004, 1015 (9th Cir. 2001) (facilitating a change in format from CD to MP3 format and changing context of recording to facilitate unlicensed uncompensated file transfer did not create a new function carrying a new appropriate fair use meaning and purpose different from the original artistic works); Infinity Broad. Corp. v. Kirkwood, 150 F.3d 104, 108-09 (2d Cir. 1998) (concluding that the change in mode and medium of communication from radio broadcast to telephone communication did not create a new function carrying a new appropriate fair use meaning and purpose different from the original artistic works); Ringgold v. Black Ent. Television, 126 F.3d 70 (2d Cir. 1997) (concluding reproduction of a story quilt image from an authorized museum poster to an unauthorized use as set dressing on television program did not create a new function carrying a new appropriate fair use meaning and purpose different from the original artistic work).

144. Compare Campbell v. Acuff-Rose Music, Inc., 510 U.S. 569, 579-84 (1994) (concluding that 2 Live Crew copied the bass riff and musical scheme of the beginning of "Pretty Woman" and proceeded to distort the music and lyrics to make a rap song that ridiculed the romantic tone and naïveté of the original rock ballad), Suntrust Bank v. Houghton Mifflin Co., 268 F.3d 1257, 1272-74, 1280 (11th Cir. 2001) (discussing that "Wind Done Gone" copied characters and situations from "Gone With the Wind" but distorted the dialogue and point of view of the work by adding a new tone and new meaning to the "race relations of the place and era" of the original), Mattel, 353 F.3d at 802-03 (discussing that the artist placed Barbie dolls in unusual settings with kitchen appliances to comment on and criticize Barbie's iconic status as a role model for young American girls), and Leibovitz v. Paramount Pics. Corp., 137 F.3d 109, 114-115 (2d Cir. 1998) (discussing that Paramount created the poster with famous portrait of a pregnant star and distorted the image by superimposing a male comedian's head onto the female star's body as a 
criticism where the object of the criticism is not the original work or the original author), may be accepted as fair use, but the new work must be highly transformed and must not exploit the same creative artistic virtues of the original for the same or similar purposes as the original. ${ }^{145}$ All of the changes in function and purpose by the authors of successful parodies and satires created a new work or a new situation of employment of the original work that furthered important First Amendment public policy goals of comment and criticism, education, or research (both as to current and historical events). The second users also produced a new work or new employment of the old work in a manner that had little competitive impact on the original work's owners' ability to continue to exploit the original functions and purposes of the original work, ${ }^{146}$

comment to the pretentious artistic styling of the original), with Salinger v. Colting, 607 F.3d 68, 73-74 (2d Cir. 2010) (discussing Colting's attempt to advance the plot of "Catcher in the Rye" by sixty years and addition of Salinger as a character in Salinger's own story to comment on and critique the original work, the main character, and Salinger's reclusive lifestyle, but in the end, finding the new work merely exploited the same creative aspects of the original novel in the manner of a derivative work, not a parody or other proper commentary or criticism), and Dr. Seuss Enters. v. Penguin Books USA, Inc., 109 F.3d 1394, 1400-05 (9th Cir. 1997) (holding that although O.J. Simpson trial story changed the entire genre, theme, tone, characters, dialogue, and plot of the original "Cat in the Hat" work, the court found no critical commentary or statement of any kind regarding or reflecting on the original Dr. Seuss work, and the court concluded that the second work merely stole and exploited the Dr. Seuss work to grab attention).

145. Compare Blanch, 467 F.3d at 244, 248 (finding that Blanch's work was used as one example of the genre of fashion imagery, and the additional creative, artistic material added by Koons and his recontextualization of the work overwhelmed any exploitive purpose in the use of the creative content reflected in Blanch's original photograph), with Salinger, 607 F.3d at 73 (explaining that the additional commentary and message added by Colting to the message of Catcher in the Rye did not change the fact that his work generally exploited the creative material of the original work by advancing the plot, rather than changing the function and purpose of the work), and Castle Rock Entm't, Inc. v. Carol Publ'g Grp., 150 F.3d 132, 142 (2d Cir. 1998) (concluding that the Seinfeld Aptitude Test did not make commentary or criticism regarding the Seinfeld series, but still exploited the same creative value and meaning of the original for the same entertainment purpose as the original), and Dr. Seuss Enters., 109 F.3d at 1400-01 (explaining that the author's "Cat Not in the Hat" commentary and criticism of the O.J. Simpson trial and the U.S. court system did not justify the exploitation of the creative artwork and rhyming style of the original Dr. Seuss work).

146. In basic terms, a new work with a completely changed message and purpose is unlikely to satisfy the fans and consumers of the original work; thus, the new work does not "supersede the objects" of the original work. E.g., 
supporting the argument that the second users' uses were fair.

The advice of this Article is not to use other's works or to modify them obviously. In cases of non-transformation, neither the contents nor the function and purpose of the original work is changed, no greater First Amendment public policy purpose is furthered beyond that served by the creation and publication of the original work, and the original work is therefore exploited for exactly the same purposes for which it was originally created. It is easy to see that these cases of selfserving exploitation are not held to be fair. ${ }^{147}$

Secondary users of artistic works might find it difficult to reconcile the several fair use cases where secondary users appear to have greatly altered significant aspects of the original works, but their uses were not found to be fair. These

Blanch, 467 F.3d at 244, 258 (finding that Koon's recontextualized use of legs from Blanch's photograph had no deleterious effect upon Blanch's photograph's market value); Leibovitz, 137 F.3d at 116-17 ("[T] he Paramount photograph did not interfere with any potential market for [Leibovitz's] photograph or for derivative works based upon it."); see also Folsom v. Marsh, 9 F. Cas. 342, 348-49 (C.C.D. Mass. 1841) (Story, J., sitting as circuit justice) (stating that fair use works do not "supersede the objects" of the original work but that exact copying of original works is not allowed); Campbell, 510 U.S. at 579 (quoting Folsom v. Marsh, 9. F. Cas. at 348).

147. See Murphy v. Millennium Radio Grp. L.L.C., 650 F.3d 295, 307 (3d Cir. 2011) (holding no fair use when photos of radio personalities were only slightly cropped to remove original photographer's copyright notice, and otherwise used without permission for the same news and promotional purposes as the original); Bouchat, 619 F.3d at 309 (holding no fair use when a non-altered drawing that formed the basis of the team's logo was used in dozens of items associated with the team); Leadsinger, 512 F.3d at 530 (holding that the non-alteration of basic elements of music when adapted for karaoke lead to a finding of no fair use); see also Zomba Enterprises, 491 F.3d at 582-83 (holding that the non-alteration of basic elements of music when adapted for karaoke lead to a finding of no fair use); Elvis Presley Enters., 349 F.3d at 628-29 (finding no fair use when the original video clips and recordings were not altered or modified in content when compiled for biographical video compilation); Video Pipeline, 342 F.3d at 198-200 (finding no fair use when the film contents were excerpted without other alteration for use in proprietary video database); A\&M Records, 239 F.3d at 1015 (holding that there is no fair use when the content and expression of the original audio recordings were not altered or modified when the works were changed in digital format and compiled to assist file-sharing); Infinity Broad. Co., 150 F.3d at 108-09 (finding no fair use when the only change in the work was a change in mode and medium of communication from radio broadcast to telephone communication); Ringgold, 126 F.3d at 70 (finding that the appearance of a story quilt poster was not altered or modified, but that only the amount shown or the timing of each display varied in the non-fair use display of the work). 
seemingly incongruous outcomes are addressed by explanatory synthesis when all of these cases are considered together to explain the common underpinning and public policy objectives pursued by the courts in these opinions: even significant alteration of the form, or genre, or theme, or tone, or even the overall meaning of the works will not be found to be fair uses if non-trivial portions of the creative, artistic, and expressive virtues of the original works shine through and are not replaced or overwhelmed by the expression in the second work. ${ }^{148}$ Aside from specific critical fair uses such as parody that rely on the exposition of certain key attributes of the original work in the second work, in other contexts, if the creative, artistic, and expressive virtues of the original works still are discernible in the second work, and still add value to the second work, the use of the original work will be deemed unfair. 149

148. Compare Gaylord, 595 F.3d at 1372-73 (holding that there is no fair use when the appearance of the Korean War Memorial was significantly altered in the photograph and postage stamp but still depicted the same artistic design and expression of the original sculpture; the artistic embellishments of the photograph and stamp did not change the meaning and function of the original work), Bridgeport Music v. UMG Recordings, Inc., 585 F.3d 267, 278 (6th Cir. 2009) (finding that hip hop group's sampling of the iconic Atomic Dog sound and lyric significantly altered the genre and context of the original, but allowed the iconic sound and expression of the original work to shine through, with that being the primary purpose of the inclusion of the same in the second work, and this improperly exploited the creative, artistic virtues of the original work), Castle Rock, 150 F.3d at 142 (finding that the Seinfeld trivia book significantly altered the form and presentation of the original television show content, but the transformation did not change the entertainment function and purpose of the original work and allowed the creative, entertaining content and expression of the original material to shine through in the second work), and Dr. Seuss Enters., 109 F.3d at 1400-07 (holding that the original artwork, graphic design, and poetic style of the original Dr. Seuss work was allowed to shine through in the second work although the style, genre, tone, and function of the plot and story of the second work was completely different from the original), with Blanch, 467 F.3d at 245 (finding the original work was used as raw material-a placeholder for a certain genre of fashion photographic depiction of women-and the artistic changes added by Koons were meant to completely change the meaning and message of the depiction for a new function and purpose), and Leibovitz, 137 F.3d at 109, 110-11 (finding the original photograph was altered specifically to change the meaning, function, and purpose of the original from a serious artistic portrait to a parody of the original work).

149. E.g., Salinger, 607 F.3d at 73; Gaylord, 595 F.3d at 1372-73; Bridgeport Music, 585 F.3d at 278; Castle Rock, 150 F.3d at 142; Dr. Seuss Enters., 109 F.3d at 1407. 


\section{B. TRAnsformation With a PREDOMinant First AmEndment EXPRESSIVE PURPOSE IN RIGHT OF PUBLICITY FAIR UsE LAW}

The good news for those who seek to follow the ethical, fair use path with regard to celebrity images and likenesses is that DIOS MIO governs the path equally well with regard to publicity rights as it does with copyright: do not use celebrities' names, images, and likenesses in your art and design works, or modify the images and likenesses in an obvious manner. Highly transformative uses that overwhelm the original celebrity image with new content and expression will be considered fair. ${ }^{150}$ Of these uses, parodies again appear to have the most potential for success because the second user is replicating the name, image, or likeness of the celebrity specifically for the purpose of making fun of the celebrity, fulfilling a valid First Amendment purpose of comment and criticism that requires the use of identifying information and imagery in order to reveal the subject of the criticism. ${ }^{151}$ Cases confirm that the use of names and images specifically to ridicule the celebrities is a fairly safe way to incorporate these names or images into

150. See Winter v. DC Comics, 69 P.3d 473, 477-80 (Cal. 2003) (finding that DC Comics featured a highly transformed image of the Winter Brothers singing duo - the two were depicted as giant albino worms rather than human singing celebrities in a general effort to denigrate the two singers); World Wrestling Fed. Enter. Inc. v. Big Dog Holdings, Inc., 280 F. Supp. 2d 413, 417424, 428 (W.D. Pa. 2003) (discussing how Big Dog T-shirt manufacturer used "dogified"-canine-morphed-images of pro-wrestlers such that the wrestlers were depicted as dogs with dog-like names and attributes, e.g., World Wrestling star, Stone Cold Steve Austin, was referred to as "Bone Cold Steve Pawstin" in Big Dog's works, in as a parody of the pro-wrestlers); Cardtoons, L.C. v. Major League Baseball Players Ass'n, 95 F.3d 959, 962-73 (10th Cir. 1996) (discussing how the Cardtoons makers criticized baseball players' egos, exorbitant salaries, and other excesses of their personalities through the device of artistic, but highly critical baseball cards that showed a transformed cartoon version of the ball player along with fake "stats" about the excesses or ego of the player).

151. See Winter, 69 P.3d at 477-80 (concluding the Winter Brothers were depicted in order to reveal the comic artist's dislike of the singing duo; the artist did not recreate their image for any exploitative purpose other than to reveal the target of the criticism); World Wrestling, 280 F. Supp. 2d at 428 (concluding that the Big Dog T-shirt manufacturer attempted to identify the targets of their spoofing with morphed images and names to suggest the "dogified" nature of the parody); Cardtoons, 95 F.3d at 962-63, 968-72 (discussing how the Cardtoons makers rendered the images of players in cartoon form, and morphed their names to reveal the targets of the criticism, e.g., Barry Bonds was renamed "Treasury Bonds" as part of the criticism that he was overpaid and overly egotistical). 
artworks and designs.

Non-critical, non-parodic artistic expression of a celebrity image or likeness is a dangerous undertaking. A few courts interpreting New York law have gone on record as taking an expansive view toward allowing the depiction of a celebrity in works of art simply to display the celebrity in art. ${ }^{152}$ California courts have made the opposite record: a simple, artistic depiction of a celebrity for commercial sale of the artwork constitutes exploitation that violates the celebrity's publicity rights. ${ }^{153}$

Significant artistic transformation of the celebrity image improves the equation in favor of fair use.154 The fame of the artist and her notoriety for this kind of artistic transformation also will improve the odds that the fair use equation will work out in favor of the artist. ${ }^{155}$ In Comedy III, the court evaluated

152. See Simeonov v. Tiegs, 602 N.Y.S.2d 1014, 1018 (N.Y. Civ. Ct. 1993) (explaining a ruling that artists may create a limited number of art works depicting a celebrity image without liability under New York's publicity law); see also Hoepker v. Kruger, 200 F. Supp. 2d 340, 349-54 (S.D.N.Y. 2002) (holding that defendant artist Barbara Kruger's use of a photographic image of a female model from the 1960's should be upheld against the model's right of publicity claim; following Simeonov, the court's holding was that Kruger's depiction involved significant artistic recontextualization and added new expression to the original image, making Kruger's use fair).

153. See Hilton v. Hallmark Cards, 599 F.3d 894, 909-11 (9th Cir. 2010) (concluding card company violated Paris Hilton's right of publicity when it created a cartoon of the celebrity repeating her famous "That's hot" line for a greeting card); Comedy III Prods., Inc. v. Gary Saderup, Inc., 21 P.3d 797, 806-09, 811 (Cal. 2001) (finding the artist violated the Three Stooges' rights of publicity when the artist created a realistic depiction of the Stooges in charcoal art reproduced for sale on lithographs and T-shirts).

154. Compare Hoepker, 200 F. Supp. 2d at 342, 349-54 (holding that the artist's recontextualization contains "sufficiently transformative elements," which consisted of cropping and enlarging the photograph as well as superimposing large red blocks that contained textual message), Winter, 69 P.3d at 478 (holding that transforming singers into albino worms was highly transformative), and Kirby v. Sega of Am., Inc., 50 Cal. Rptr. 3d 607, 609, 616 (Cal. Ct. App. 2006) (transforming an image of former disco star, Kirby-Lady Miss Kier-into an animated avatar, and transforming a refrain from one of the star's songs, "Ooh la la," into the name of the avatar, "Ulala" is fair use), with Comedy III, 21 P.3d at 811 (arguing that a defendant's artistic rendering in charcoal did not sufficiently transform the conventional image of the Three Stooges to succeed against Stooges' publicity claim).

155. See Hoepker, 200 F. Supp. 2d at 342, 349-50 (stating that the artistdefendant, Barbara Kruger, is a "well-known artist, specializing in collage works combining photographs and text"; her cropping and enlargement of the 1960's photograph as well as superimposing large red blocks that contained 
the fame, artistic reputation, eye-catching technique, and starpower of Andy Warhol, holding that the artist overwhelmed the value of the celebrities' images that shown through in the artist's works. ${ }^{156}$ Gary Saderup, the artist-defendant in Comedy III, might have had a following for his realistic depictions of celebrities, but they were not presented in the context of some greater ironic statement or commentary about the meaning or message of the "stars" of his works. Saderup's works were simple, faithful, realistic, artistic depictions of the celebrities, and as such, were held to violate the publicity rights of the celebrities. ${ }^{157}$

The lesson for lawful, ethical treatment of celebrities' names, images, and likenesses is that depiction of a celebrity to communicate the meaning or message or the actual attributes of the celebrity herself, absent any commentary on or criticism of the meaning and message or symbolism of the celebrity or her actions, is very likely to be found to be an unethical and unlawful exploitation of the celebrity's publicity rights. If you modify the celebrity image's appearance with a highly stylized, recognizable method or technique that is original to you and

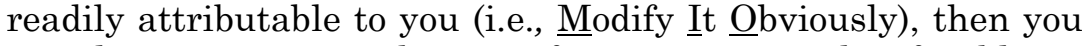
greatly improve your chances of success in a right of publicity claim. You may not have to be as famous as Warhol or even Barbara Kruger, but the degree to which observers will say, "That is a great picture by [your name]," rather than, "That is a great picture of [celebrity's name]," is a measure of the potential success you should expect if you choose to depict celebrity images in your art.

Commentary and criticism and artistic transformation are not the only First Amendment expressive purposes that might be served by the use of a celebrity name, image, or likeness. There is a general exception to liability for the reporting of genuine newsworthy information about matters of public

textual message was held to be a fair use because of its artistic transformation and new expression added to the image); Comedy III, 21 P.3d at 811 (stating that Andy Warhol is a model for an artist whose works were valuable because they were obviously his own through "distortion and careful manipulation of context," and not because they depicted Elvis, Marilyn Monroe, or Elizabeth Taylor).

156. See Comedy III, 21 P.3d at 811.

157. See id. 
interest. 158 This has been extended to the depiction of celebrities and celebrity sports figures in the context of providing news and public affairs information about the sports they play, 159 and commentary about the meaning and importance of the athlete's achievements. ${ }^{160}$ The public interest and public affairs exception even has been extended to protect dissemination of information regarding current fashion trends in apparel. ${ }^{161}$

It should be noted that news informational uses must be genuine; one cannot simply celebrate the celebrity of the moment by recreating their image and likeness in a work and claiming that the use is intended for spreading news and public interest information about the celebrity. ${ }^{162}$ Persons enjoying

158. Clay Calvert, Every Picture Tells a Story, Don't It? Wrestling With the Complex Relationship Among Photographs, Words and Newsworthiness in Journalistic Storytelling, 33 COLUM. J.L. \& ARTS 349, 353-58 (2010); Diane Leenheer Zimmerman, Who Put the Right in the Right of Publicity?, 9 DEPAUl-LCA J. ART \& EnT. L. 35, 53-59 (1998); see also DUBOFF, MuRRAY \& KING, DESKBOOK OF ART LAW, supra note 77, at Bk. S.

159. See C.B.C. Distribution \& Mktg., Inc. v. Major League Baseball Advanced Media, L.P., 505 F.3d 818, 823-24 (8th Cir. 2007) (holding that the use of major league baseball players' names, stats, and likenesses in fantasy baseball game is protected by the newsworthiness and public affairs exception); ETW Corp. v. Jireh Publ'g, Inc., 332 F.3d 915, 928 (6th Cir. 2003) (holding that an artistic depiction of Tiger Woods during his first victory at the Masters was fair use); Hart v. Electronic Arts, Inc., 740 F. Supp. 2d 658, 665 (D.N.J. 2010) (holding that use of collegiate football player's avatar in football simulation video game was not a violation of publicity rights).

160. See ETW, 332 F.3d at 931, 936 (finding that the artist's depiction of Tiger Woods' during Woods' historic win at the Masters was permitted in part because of public interest in newsworthy athletes and sporting events).

161. See Hoffman v. Capital Cities/ABC, Inc., 255 F.3d 1180, 1185-86 (9th Cir. 2001) (finding that the movie star's image shown in photograph while playing a famous movie role was allowed to be modified for use in an article presenting "a combination of fashion photography, humor, and visual and verbal editorial comment on classic films and famous actors" that fell under the public affairs exception).

162. Compare Hilton v. Hallmark Cards, 599 F.3d 894, 910-11 (9th Cir. 2010) (holding that Hallmark Cards could not depict the socialite and sometime reality TV star, Paris Hilton, in a greeting card cartoon that played off of Hilton's reality TV role as a waitress and her general notoriety; the use was found to be unfair), and Parks v. LaFace Records, 329 F.3d 437, 452-58 (6th Cir. 2003) (holding that OutKast hip hop group's use of Rosa Park's name, although intended to be "metaphorical' or "symbolic," was not about Rosa Parks in biographical sense, and it "unquestionably enhanced the song's potential sale to the consuming public," which raised the genuine issue of material fact whether this use was unfair), with ETW, 332 F.3d at 931, 936 (holding that the "Wood's victory in the 1997 tournament was a historic event 
the news and information services exception do not necessarily have to be full-time members of the press, ${ }^{163}$ but they must be involved in a concerted effort to disseminate news and information, not simply producing a one-off depiction of a celebrity in an artwork or design.

Celebrities lead newsworthy lives-it is a coincidence of factors relating to a person's public interest and news potential that leads to the person being identified as a celebrity-but not every use of a name, image, or likeness of a celebrity can be justified as news or public interest in public affairs expressive activity. Advertising and promotional uses of celebrities' names, images, or likenesses in the sale of goods or other commercial activities are the classic instances of violations of the celebrities' rights of publicity, even if the particular image or footage used has or had, at least at some point, news and public interest value. ${ }^{164}$

in the world of sports" and that "[a] piece of art that portrays a historic sporting event communicates and celebrates the value our culture attaches to such events" was found to be fair).

163. See ETW, 332 F.3d at 918-19 (noting the artist was a sports artist, not a newsperson, and did not publish his painting and serigraphs in any news outlet).

164. See Hilton, 599 F.3d at 909-11 (determining the socialite and sometime reality TV star, Paris Hilton, became the subject of a Hallmark greeting card that featured an artistic, cartoon rendition of Hilton playing off of Hilton's tag line, "That's hot," and her reality TV role as a waitress); Toffoloni v. LFP Publ'gGrp., 572 F.3d 1201, 1213 (11th Cir. 2009) (concluding Hustler Magazine was not permitted to feature twenty-year-old nude and partially nude photographs of one-time wrestler, Nancy Benoit, in a 2008 issue of the magazine following Benoit's murder in 2007; neither the newsworthiness of the murder, nor the past-fame or notoriety of Benoit provided a justification for exploitation of twenty-year-old images of Benoit for purposes of promoting the current, 2008 sales of the magazine); Bosley v. Wildwett.com, 310 F. Supp. 2d 914, 925-29 (N.D. Ohio 2004) (concluding adult video makers were not permitted to display wet t-shirt images of news anchorwoman in the context of promoting the sale of adult video products); Abdul-Jabbar v. General Motors Corp., 85 F.3d 407, 416 (9th Cir.1996) (remanding the case to trial based on sufficient facts shown by Abdul-Jabbar that General Motors's advertisement for Oldsmobile automobiles during the NCAA basketball tournament with footage of Abdul-Jabbar playing college basketball was exploitative and not a fair use; the newsworthiness of AbdulJabbar's basketball record did not succeed in overcoming the fact that the images were predominantly used to draw attention to General Motors' attempt to sell automobiles); Midler v. Ford Motor Co., 849 F.2d 460, 462 (9th Cir. 1988) (remanding the case to trial based on sufficient showing that Ford Motor Company's ad mimicking the singing voice of Bette Midler in order to advertise and sell Ford automobiles may not be a fair use). 
In Zacchini, the only right of publicity case adjudicated by the United States Supreme Court, the high court held that the unauthorized broadcast of the entire fifteen second performance of a "human cannonball" act (Mr. Zacchini being the aforementioned cannonball) at a county fair, aired in the context of a regular nightly news broadcast in a segment devoted to local human interest stories, still violated Zacchini's right of publicity because it was unfair and exploitative to air for free the entire act of a performer who earns his livelihood from these fifteen second performances. ${ }^{165}$ The First Amendment rights of a member of the press timely engaged in reporting a bona fide news story were overcome by the rights of the celebrity not to have his livelihood threatened by this usurpation of his publicity rights. This case should send a clear message to artists and designers to play fairly with celebrity images and likenesses, because fair and ethical handling of publicity rights is a significant concern of the courts that will, in proper circumstances, outweigh even a powerful First Amendment expressive justification for the use of the celebrity name, image, or likeness.

\section{CONCLUSION}

The good news for the ethical artist and designer is that the same activities of creation that support copyrightability of the artist's or designer's own work will also support the fairness of use of others' works or their images or likenesses. If the artist's or designer's motive is to be creative-to create new content, meaning, and expression-and not exploitative- to rip off another to avoid the drudgery of being creative-then the artist's or designer's works will be copyrightable and uses of others' works and their names, images, and likenesses will be fair and ethical. Exploitation of famous celebrity images follows the same path: depiction of a celebrity to communicate the meaning or message or the actual attributes of the celebrity herself, absent any commentary on or criticism of the meaning and message or symbolism of the celebrity or her actions, is very likely to be found to be an unethical and unlawful exploitation of the celebrity's publicity rights. If an artist depicts a celebrity for the purpose of criticizing the celebrity,

165. See Zacchini v. Scripps-Howard Broad. Co., 433 U.S. 562, 569-78 (1977). 
her use is likely to be found to be fair. Alternatively, if the artist modifies the celebrity image's appearance with a highly stylized, recognizable method or technique that is original and readily attributable to the artist (i.e., Modify It Obviously), then the artist has greatly improved her chances of success in a right of publicity claim.

The DIOS MIO recommendation reminds artists and designers that plagiaristic motives are recognized in the arts as well as in literary and academic endeavors. Crass exploitation of valuable works or celebrity images so that the expressive value of these works or images might be credited to the artist as new, creative expression conceived of and executed by the artist will be regarded as an act of unfair and unethical exploitation. The label-copycat, derivative, infringer, pirate, or plagiarist-is not as important as the motivation that is coupled with the action. The gray and black areas of potentially unethical behavior are avoided if you "Don't Include Other's Stuff, or Modify It Obviously.” 